\title{
Designing New Money The Policy Trilemma of Central Bank Digital Currency
}

\author{
Bjerg, Ole
}

Document Version

Final published version

Publication date:

2017

\section{License \\ CC BY-NC-ND}

Citation for published version (APA):

Bjerg, O. (2017). Designing New Money: The Policy Trilemma of Central Bank Digital Currency. Copenhagen Business School, CBS. MPP Working Paper

Link to publication in CBS Research Portal

\section{General rights}

Copyright and moral rights for the publications made accessible in the public portal are retained by the authors and/or other copyright owners and it is a condition of accessing publications that users recognise and abide by the legal requirements associated with these rights.

\section{Take down policy}

If you believe that this document breaches copyright please contact us (research.lib@cbs.dk) providing details, and we will remove access to the work immediately and investigate your claim. 


\title{
Designing New Money \\ - The Policy Trilemma of Central Bank Digital Currency ${ }^{1}$
}

\author{
Ole Bjerg $^{2}$
}

\section{CBS Working Paper}

June 2017

1 The paper is part of the research project 'Monetary Reform for the Post-Growth Economy' and it is supported by the KR-Foundation grant No. 1503-01701.

2 Department of Management, Politics and Philosophy, Copenhagen Business School, Porcelænshaven 18A, 2000 Frederiksberg, Denmark. Phone: (45) 38152813 and e-mail: ob.mpp@cbs.dk 


\title{
Designing New Money - The Policy Trilemma of Central Bank Digital Currency
}

\begin{abstract}
:
The prospect of central banks issuing digital currency (CBDC) immediately raises the question of how this new form of money should co-exist and interact with existing forms of money. This paper evaluates three different scenarios for the implementation of $\mathrm{CBDC}$ in terms of their monetary policy implications. In the 'money user scenario' CBDC co-exists with both cash and commercial bank deposits. In the 'money manager scenario' cash is abolished and CBDC co-exists only with commercial bank deposits. And in the 'money maker scenario' commercial bank deposits are abolished and CBDC co-exist only with cash. The evaluation is based on an adaption of the classical international monetary policy trilemma to a domestic monetary system with multiple forms of money. Our proposition is that a monetary system with two competing money creators, the central bank and the commercial banking sector, can simultaneously only pursue two out of the following three policy objectives: Free convertibility between CBDC and bank money, parity between CBDC and bank money, and central bank monetary sovereignty, which is the use of monetary policy for anything else than support for commercial bank credit creation. This means that the decision on the design of a monetary system with CBDC implies a crucial political decision on the priorities of the central bank.
\end{abstract}

Keywords: $\quad$ Central banks, money creation, digital currency, monetary policy, policy trilemma

JEL classification: E40, E41, E42, E50, E51, E52, E58, E61, G21 


\section{Content}

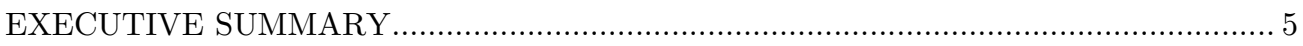

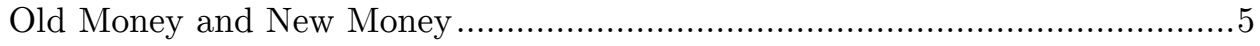

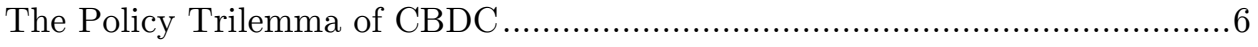

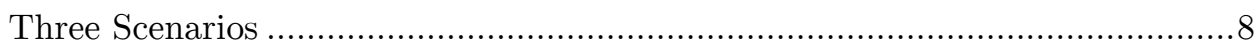

INTRODUCTION

From Monetary Policy to Monetary Politics............................................... 9

Current Debate and Research ....................................................................... 11

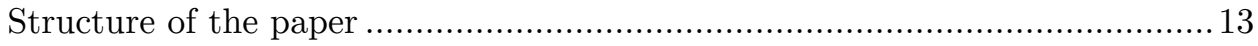

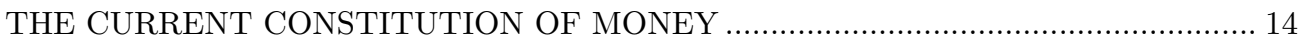

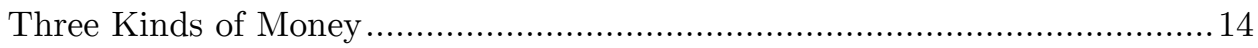

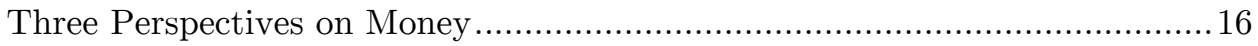

WHAT IS CBDC?

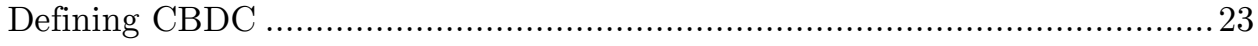

Electronic Cash, Universal Reserves, or Sovereign Account Money? ..............25

The Monetary Policy Trilemma of CBDC ….............................................28

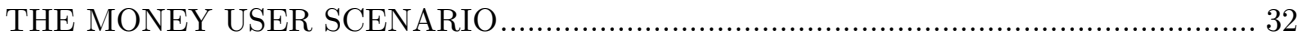

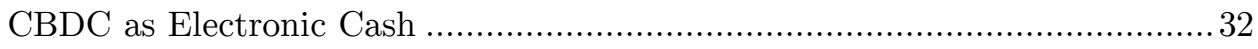

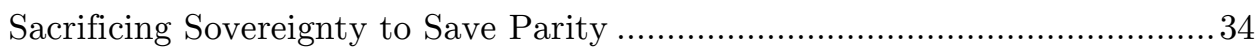

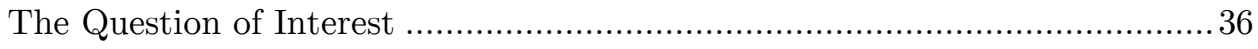

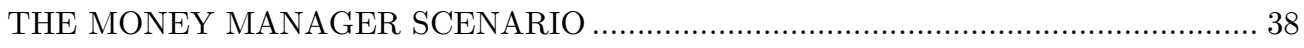

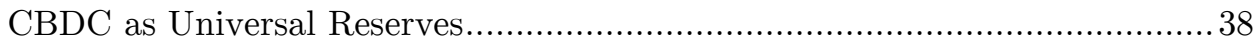

Making Good Money Worse ................................................................... 40

Money Supply or Money Demand …............................................... 41

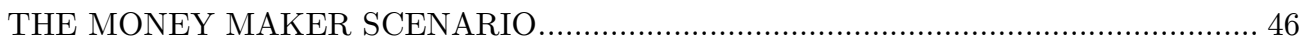

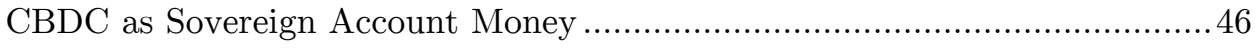

Integration of Monetary and Fiscal Policy ..................................................4 48 


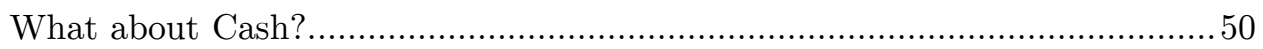

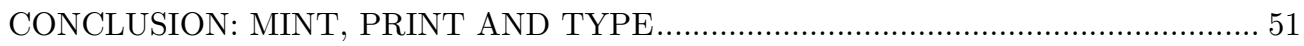

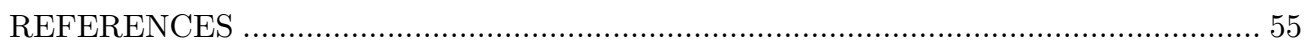




\section{Executive Summary}

The prospect of central banks issuing digital currency not only raises the question of whether this is a good idea or not. There are a number of variables in the design of a central bank digital currency (CBDC) thus raising the question how to design such a new form of money. This is the question explored in this paper.

The paper poses the question of the design of CBDC not merely as a technical but also a political question. Before we are able to determine, what is the optimal design of $\mathrm{CBDC}$, we have to decide, what we want this kind of money to do for us. What is the purpose of implementing CBDC? This is a political question in so far as different CBDC design models serve the interest of different groups of agents in the economy. The purpose of the paper is to point out the political nature of the question of CBDC as well as to map out different scenarios for the design and implementation of this kind of money.

\section{Old Money and New Money}

The paper defines CBDC in relation to the three kinds of money constituting the existing monetary system: cash, bank money and central bank reserves. The characteristics of these three kinds of money relative to CBDC are analyzed through the Venn diagram below. 


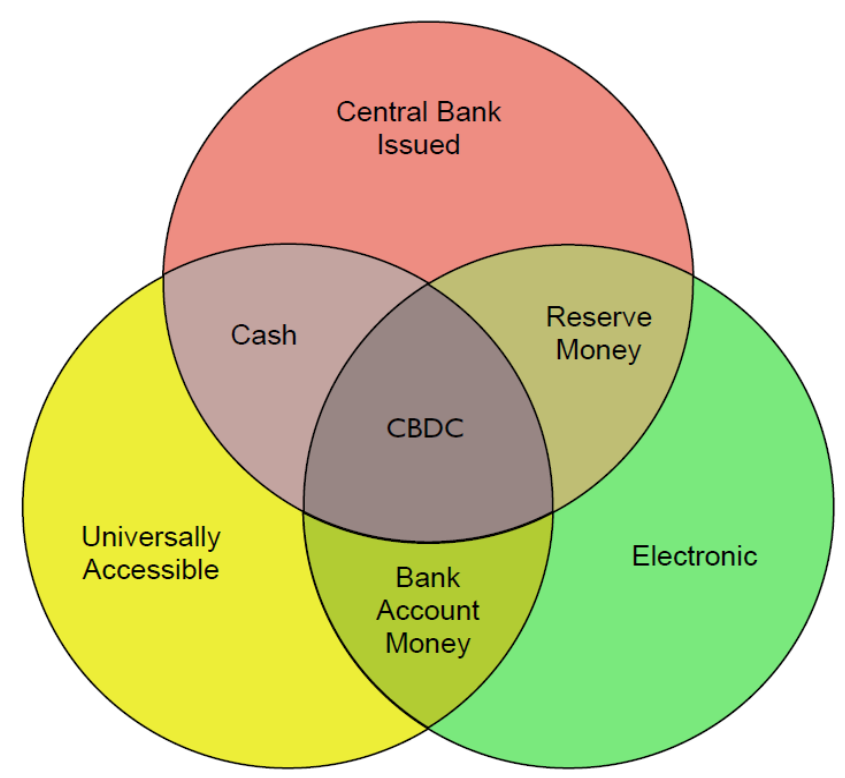

The idea is that each of the existing forms of money is defined through the lack of one of the three features: electronic, universal and central bank issued. The illustration also shows how CBDC integrates all of these three features. CBDC thus potentially competes with each of the three existing forms of money. This allows us to pose the question of the design of CBDC in terms of the way that CBDC should supplement or replace any of the existing forms of money. Assuming that CBDC replaces existing central bank reserve money, the issue of the design of CBDC may be broken down into two key questions:

- Should cash be abolished with the implementation of CBDC or should the two forms of money co-exist?

- Should bank money be abolished with the implementation of CBDC or should the two forms of money co-exist?

Depending on the way that these two questions are answered, there are four different ways of combining CBDC with existing money each constituting a particular design model of the monetary system:

1) CBDC as complimentary to both cash and bank money

2) CBDC as a replacement for cash and complimentary to bank money

3) $\mathrm{CBDC}$ as a replacement for both cash and bank money

4) CBCD as complimentary to cash and a replacement for bank money.

The monetary policy implications of model 3) and 4) are not considered to differ significantly and they are thus treated as one model. 
The Policy Trilemma of CBDC

In order to evaluate the policy implications of each of these three design models, the paper develops an adapted version of Mundell, Fleming and Obstfeld's classic monetary policy trilemma. The conventional trilemma illustrates the relations between a domestic and a foreign money creator in the form of two different central banks. Our trilemma illustrates the relations between two domestic money creators in the form of the central bank and the commercial banking sector. The domestic monetary policy trilemma is posed in the following fashion:

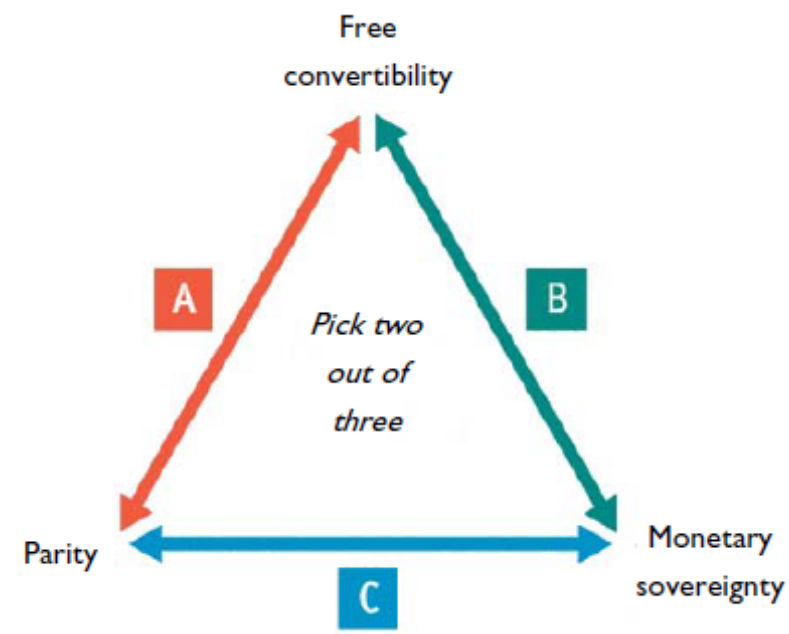

- The conventional policy objective of exchange rate management between two currencies translates into the domestic policy objective of securing financial stability by maintaining parity between commercial bank money on the one hand and CBDC and cash on the other.

- The conventional policy objective of monetary autonomy in decisions on central bank interest rates translates into monetary sovereignty, which is the prerogative of the monetary authorities to use CBDC not only as a monetary policy tool to support commercial bank credit creation but also as a fiscal policy tool to stimulate the general economy. The abandonment of monetary sovereignty means that commercial banks are the primary drivers of money creation.

- The conventional policy objective of free capital mobility translates into free convertibility between commercial bank money and central bank money. We may understand the implementation of CBDC as the introduction of such 
convertibility. With universal access to the central bank balance sheet, ordinary money users now for the first time have the option to choose between holding electronic money with the central bank or with commercial banks.

The gist of the trilemma is that monetary authorities can only pursue two out of the three policy objectives.

\section{Three Scenarios}

The main analytical section of the paper applies the domestic monetary policy trilemma to each of the three possible CBDC design models. The current situation, where convertibility between commercial bank money and central bank money is highly inconvenient for money users as they would have to hold physical cash, means that the monetary authorities are now in the $(\mathrm{C})$ position. The introduction of CBDC opens up the possibility of free convertibility between commercial bank money and central bank money. This means that the central bank must either give up using monetary policy and interest rate adjustments for any other purpose than defending parity (A). Such approach would immediately correspond to design model (1). But pressure on parity could ultimately force the central bank to phase out cash to allow for CBDC interest rates going negative thus leading to design model (2). Another option is for the central bank to give up taking responsibility for parity between CBDC and bank money (B). This would amount to design model (3) or (4) as bank credit money would no longer have the status of money but be merely a particular form of commercial credit. 


\section{Introduction}

\section{From Monetary Policy to Monetary Politics}

One of the great questions of counterfactual history is this: What would the world look like today, if John Maynard Keynes' proposal for a Bancor had been adopted at the 1944 Bretton Woods Conference? The Bretton Woods system came to define the exceptional role of the United States in the global economy by establishing the US-Dollar as the anchor of the international monetary order thus making it the new world reserve currency. In contrast to this model, Keynes had envisaged a truly supranational currency in the form of the Bancor, which would be beyond the control of any single state and thus put all of the national currencies on an equal footing. Thinking through the hypothetical scenario of an adoption of the Bancor proposal brings to mind the real economic and political significance of an initially technical difference in the design of a monetary system. The technical design of the Bretton Woods was constitutive for the post-war economic world order.

The topic of the current paper is the proposal of implementing central bank issued digital currency (CBDC). Hiding behind the inconspicuous acronym CBDC is nothing short of an entirely new form of money. While the true potential of such an arrangement may not be immediately evident to the non-expert eye, it could nevertheless constitute a radical innovation in the constitution of our money system in the same category as the introduction of paper money. As in the case of the Bancor and the Bretton Woods, it is crucial to understand how technical differences in the design of CBDC has profound economic and political implications, when this new money is implemented. The purpose of the paper is to bridge the technical dimensions with the economic and political dimensions of the question of CBDC.

In the immediate aftermath of the financial crisis of $2007-8$, there was a window of opportunity for financial reform. Banks and private financial institutions were on their knees. They were in need of liquidity to prevent money markets from freezing, assets prices from deflating and themselves from going into insolvency. Governments and regulatory bodies could have used this opportunity to 
impose reforms on the banking sector not only to create a more stable system but also take back some of the control over the economy and society, which had been concentrated in the financial sector over the past four decades of increasing financialization.

Instead of exploiting this opportunity for change, the general trend in the responses from governments of the economies struck by crisis was to aim for a restoration of status quo. The first priority was to bail out the banks by using the central banks as providers of ample amounts of cheap money as well as sinks to offload toxic assets. These state subsidies to the banks were presented as inevitable technocratic measures and their true content obscured under acronyms such as TARP and QE. Not only did they serve to reboot the balance sheets of private financial corporations and allow them to swiftly return to pre-crisis levels of profit making, they also shifted the balance of economic and political power back to the advantage of the financial sector. The burden of the crisis was transferred onto the public budgets and the central bank balance sheets with ordinary citizens and taxpayers left to pay the bill in the form of austerity, public utility privatizations, political impotence and continued anxiety of when the next crisis is going to strike.

The idea of central banks issuing universally accessible digital money has been circulating among academics and activists for more than a decade (Huber and Robertson 2000; Jackson and Dyson 2012; Binswanger, Huber, and Mastronardi 2012; Bjerg 2013; Huber 2014; Dyson and Hodgson 2016; Huber 2017). The true novelty is that within the past 1-2 years, central banks have begun to publicly announce interest in the idea. Here is how the Bank of England speaks about the matter:

If a central bank were to issue a digital currency everyone, including businesses, households and financial institutions other than banks, could store value and make payments in electronic central bank money in addition to being able to pay with cash. While this may seem like a small change, it could have wide-ranging implications for monetary policy and financial stability. (Bank of England 2017)

This opens a new window of opportunity for monetary policy measures that do not just serve to patch up the existing system but engages with its core fundamentals. If we think of monetary policy as incremental adjustments to continuously calibrate an existing system, the question of CBDC should be conceived as 
a matter of monetary politics. Policy is a plan to achieve certain predefined ends. Politics is the discussion, decision and thus definition of these ends.

There are plenty of reasons to be excited about the growing interest in CBDC from people and institutions, who actually have the power to make it happen. At the same time it is also important to insist that the question of whether and how to implement this new form of money should not only be a decision made by central bankers. The responsibility of central bankers is to implement monetary policy. It is not to make political decisions on money. The hallmark of democratic societies is the involvement or at least the representation of those citizens affected by a political decision in the making of this decision. This is especially the case with constitutional matters such as the making of laws, the collection of taxes, or the use of legitimate force. Decisions on who should create which kinds of money in our society belong in that same category. The aim of this paper is thus to broaden the scope of the debate on CBDC to include people outside of the narrow circles of central bankers and other monetary policy insiders.

\section{Current Debate and Research}

In February 2015, the Bank of England posed the following question in its 'One Bank Research Agenda':

From a monetary and financial stability point of view, what are the costs and benefits of making a new form of central bank money accessible to a wide range of holders? (Bank of England 2015, 31)

Since the initial formulation of the question of CBDC, the Bank of England has launched a research program on the topic as well as made several public announcements discussing the prospects of implementing its own digital currency (Broadbent 2016; Carney 2016; Cleland 2016). Comparable efforts are found in other central banks around the world. The Peoples Bank of China recently stated in Bloomberg:

In recent years, digital currencies have shown considerable promise. Research by the People's Bank of China suggests that the best way to take advantage of these innovations is for central banks to take the lead, both in supervising private digital currencies and in developing digital legal tender of their own. At the PBOC, this effort is underway. ... Since 2014, under the guidance of Governor Zhou Xiaochuan, the PBOC has attached high importance to the development of legal digital currency. (Yifei 2016) 
In similar vein, the Swedish Riksbank stated in November 2016:

The Riksbank is one of the central banks that will need to take an active stance on whether or not to issue a digital currency first. We cannot wait any longer, and I shall now tell you what we intend to do in the coming years. (Skingsley 2016)

Other central banks reported to have initiated research into Central Bank Digital Cash include at the time of writing least the central banks of Canada, Russia, Senegal, Norway, Australia, Japan, Singapore and Hong Kong. David Andolfatto has floated the idea of a FedCoin, which would be a US version of CBDC, although he was not speaking on the issue in his capacity of Vice President of the Federal Reserve Bank of St Louis but as a private individual (Andolfatto 2015, see also Koning 2016). The issue has subsequently been picked up by Federal Reserve Governor Jerome H. Powell, who discussed it briefly in a speech (Powell 2017). Recently, the issue has also been raised in a speech by a representative of the European Central Bank:

The ECB would in particular have to understand the impact - positive or negative - of DBM [Digital Base Money - OB] on our primary objective of price stability before considering introducing it. Moreover, any value judgement on DBM needs to be assessed against a number of high-level principles, namely (1) technological safety, (2) efficiency, (3) technological neutrality, and (4) freedom of choice for users of means of payments. (Mersch 2017)

And the European Parliament has commissioned a report quite boldly stating that:

A digital currency could also be issued by the central bank and potentially substitute for bank deposits as the main form of money holding of households and businesses. This would challenge the present fractional reserve system at its core. Increased instability of monetary aggregates and credit supply would be a possible outcome, if market participants shifted liquidity pro-cyclically between digital money and bank deposits. Commercial banks would increasingly have to rely on other funding sources than deposits, so that this disruptive change to the fractional reserve system could finally pave the way for a more stable financial system. (Fiedler et al. 2017)

In response to these announcements, researchers have already started to evaluate the possible implications of CBDC. Probably the first and certainly the most comprehensive study of the issue so far is the paper 'The macroeconomics of central bank issued digital currencies' (2016) by Barrdear and Kumhof from the Bank of England. This is a DSGE modeling of the effects on growth, inflation, 
interest rates as well as a number of other macroeconomic variables from the implementation of CBDC. A series of other papers take a more theoretical approach by developing conceptual frameworks for discussing the risks and opportunities in implementing CBDC. These papers come from different institutions such as the Bank of Canada (Fung and Halaburda 2016), the Swedish Riksbank (Camera 2017 by commission), the FirstRand Bank in South Africa (foundery 2016), the Inter-American Development Bank (Ketterer et al. 2016), Banco Bilbao Vizcaya Argentaria (Gouveia et al. 2017), as well as the NGO Positive Money (Dyson and Hodgson 2016).

\section{Structure of the paper}

The paper begins with a description of the current monetary system, which consists of three kinds of money: cash, bank money and central bank reserves. The description of existing money forms a baseline for the subsequent definition of CBDC and evaluation of its possible implications. The description is then complemented with a distinction between three different perspectives on the nature and functioning of money. Depending on the way we think about money, we will have different kinds of concerns with regards to the implementation of a new form of money in the form of CBDC.

In the next part of the paper we define CBDC in relation to the three kinds of existing money and make a preliminary sketch of different kinds of CBDC design models. This leads into a discussion of the conventional monetary policy trilemma, which is normally applied to relations between different currencies. We adapt this trilemma to a domestic situation with multiple kinds of money denominated in the same currency.

The final part of the paper is an analysis of the monetary policy implications of each of the different CBDC design models. The adapted monetary policy trilemma is applied to three different scenarios, which is derived from the three different perspectives on money: the money user scenario, the money manager scenario and the money maker scenario. The analysis considers issues of parity, interests, money supply and sovereignty.

The paper ends with a conclusion summing up the results. 


\section{The Current Constitution of Money}

\section{Three Kinds of Money}

In order to understand the possible implications of the introduction of CBDC, it is useful to first look at the forms of money in our existing payment and banking system. In this system, we find three different kinds of money: physical cash (notes and coins), bank money on account and central bank reserve money. The interaction between these three kinds of money in the creation, circulation and destruction of money is described in great detail by a number of authors (see Werner 2005; Ryan-Collins et al. 2011; Jackson and Dyson 2012; Huber 2014; McLeay, Radia, and Thomas 2014; Huber 2017). Instead of reiterating these descriptions, we shall summarize the nature of existing money according to three questions:

What counts as this kind of money?

Who can use this kind of money?

Where does this kind of money come from?

The first may be understood as the question of the ontology of a particular form of money, the second as a question of accessibility, and the third as a question of supply.

As cash we count the legitimate paper notes and metal coins in circulation in the economy. This kind of money is accessible to all money users in the economy including private money users, commercial banks, central banks and governments. Cash is typically printed, minted and supplied by the central bank. In some cases such as UK and US only the printing of paper notes is undertaken by the central bank while the minting of coins is the prerogative of the treasury. Cash is supplied in response to demands from money users, who want to exchange their bank money for cash. This transaction is mediated by the commercial banks that purchase cash for central bank reserve money in order to accommodate the demand from money users.

As bank money on account we count electronically recorded deposit account liabilities on the ledgers of commercial banks. This bank deposit account money constitute assets for money users. Bank money is accessible to all money 
users in the economy in so far as they have a bank account. Bank money is supplied into the economy, when commercial banks credit the deposit accounts of money users. This typically happens as part of the extension of loans to borrowers. Money users thus exchange debt for bank money. Bank money may also be created as part of financial trading, when sellers of financial securities or cash happen to hold deposit accounts with the bank, which are then credited as payment of the bank's purchase of securities or cash. It is also possible for commercial banks to create bank money, when they make payments of salaries, goods purchases or dividends to employees, suppliers or shareholders, who happen to hold deposit accounts in the bank. When deposit account holders make debt repayments or interest payments to the bank, bank money is destroyed.

As central bank reserve money we count electronically recorded current account liabilities on the ledgers of central banks. This money is only accessible to money users that hold an account with the central bank. Central bank account holders typically only include commercial deposit banks, the treasury and foreign central banks. In some cases, certain non-bank financial institutions as well as employees of the central bank may also hold an account with the central bank and thus have access to central bank reserve money. Central bank reserve money is mainly supplied by being credited to commercial banks' current accounts as part of the purchase of governments bonds or certain other financial securities. Commercial banks may also borrow central bank reserve money from the central bank, which are then credited to their account. Such borrowing normally requires the commercial banks to post collateral in the form of financial securities. Central banks also create reserve money, when they credit the government's account in the central bank as payment of dividends or in exchange for government bonds. Such direct monetization of government debt is, however, prohibited under the EU Lisbon Treaty $(\S 26)$. It is also possible for the central bank to create new reserve money by crediting the accounts of foreign central banks in exchange for foreign currency reserve money.

Comparing these three kinds of money in terms of ontology, accessibility and supply, we can group them in three pairs each sharing a particular feature, which the third kind lacks:

- Bank money and central bank reserve money are both electronic, which cash is not. 
- Cash and bank money are both universally accessible, which central bank reserve money is not.

- Cash and central bank reserve money are both supplied by the central bank, which bank money is not.

This logic is illustrated in the Venn diagram below (Figure 1):

Figure 1: The features of existing money

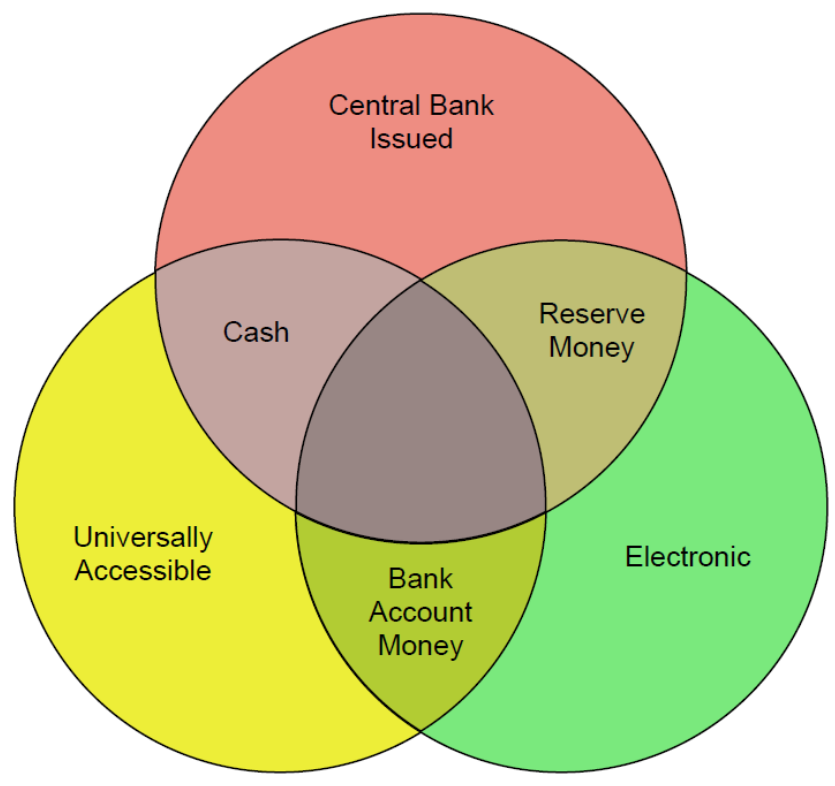

We shall return to this diagram later.

\section{Three Perspectives on Money}

It may seem that with the description of our current money system as constituted by three different kinds of money, we have been jumping ahead of ourselves. Do we not need an initial definition of money before we proceed to describe, what counts as money? What about treasury bills and government bonds? What about money market instruments? What about Bitcoin? What about gold? Are these not also different kinds of money?

Discussions about the definition of money are usually raised through the question: What is money? And this question is usually settled through a listing of the three functions of money: medium of exchange, store of value, unit of account. This kind of textbook account of money, however, suffers from a confusion of two 
things. It answers the question of what money is by listing what money does. While the distinction between the three functions of money is indeed useful, this should not lead us to conclude that it has provided us with a definition of money.

If we dig below the surface of textbook economics and explore the history of the discipline, we find that there is in fact no consensus on the definition of money. What we find instead is a number of different answers to the question: What is money. In another work, I have mapped out these answers and grouped them into three different theories or schools of thinking: the commodity theory, the state theory and the credit theory (Bjerg 2014). While these different theories may be identified and personified in particular thinkers in the history of economics, they also constitute three ideal typical perspectives on money that coexist and compete in contemporary discourses on money. The distinction between these three different perspectives on money is relevant in the discussion of CBDC, as we can use it to group different kinds of concerns and interests regarding the design and implementation of this new kind of money. The three perspectives are summarized in the following:

\section{The money user perspective}

What would you answer a four year old child, who asked the questions: What is money? Even though money is used for a variety of purposes such as settlement of debts, comparison of value, payment of taxes, saving, speculation, etc. the arch typical image of money in action is probably the exchange of money for commodities in a store. Chances are, this is also the example that you would invoke in your answer to the child: Money is a thing that we use to buy milk, carrots, bread and other commodities at the supermarket. And to further illustrate the point, you might show the child a 100 kroner note and some coins and say: This is money?

The 'cash in the supermarket' example of money, puts to the fore the function of money as medium of exchange. This is the so-called commodity theory of money (Bjerg 2014, 90-96). The obvious reference point is Adam Smith's classical story about the butcher, the brewer and the baker, who overcome the 'clogged and embarrassed' operations of barter by adopting precious metals as means of exchange (Smith 1776, 24). The gist of the story is the explanation of how money emerges as one particular commodity, usually gold or silver, that is 
singled out as a generally accepted medium of exchange to perform the function of payment for all other commodities.

We shall refer to this as the money user perspective on money. The vantage point of the money user perspective is the private individual or company, for whom money is primarily a means to buy and sell commodities, services, capital, labour, etc. The money user is thus first and foremost concerned with the functioning of money as a medium of exchange: Which kinds of money can be used to make payments in the supermarket? How can I use my mobile phone to transfer money? Does my company have to accept payments in cash? What happens to people without a bank account, when more and more payment systems are digitalized? These concerns also include questions of security and privacy: Can my my bank account be hacked when I make payments over the internet? Can the government and others trace my use of money, when I make electronic payments? Can crime and illicit economic activities be inhibited through the abolition of cash? From the money user perspective the difference between cash and bank money is merely one of practical functionality. The former is physical and the latter is electronic. Since central bank reserve money is not available to the ordinary money user, this kind of money barely registers in this perspective.

\section{The money manager perspective}

What would we answer an eight year old child, who asked the question: What is a bank? A simple answer would be that a bank is a place that keeps our money safe, so we don't have to worry about losing our money or being robbed. A bank is a place that stores money. If the child is smart, we might make our answer slightly more sophisticated by explaining how people with a lot of money put them into the bank, where people with less money may then go and borrow money. And if the child is very smart, we might tell the full story that today banks are the primary suppliers of money in the economy since the money that we use for our electronic payments are credits with commercial banks. This bank account credit money are borrowed into existence when money users take out new loans.

When we shift our perspective from the 'cash in the supermarket' to the 'debt in the bank' image, we arrive at a very different understanding of money. We do not go to the bank in order to buy goods and services. We go there to get a loan or pay off our debts and interest. And while banks do of course use money to pay 
salaries to their employees and to buy different kinds of inventory, their defining characteristic is the capacity to issue liabilities that maintain a stable value over time and thus function as the supply of money in the economy. The value of contemporary bank account money is not 'stored' in commodities such as gold or other kinds of money such as cash or reserve money. The assets 'mirroring' the value of deposit liabilities on bank balance sheets largely consist of loans to different kinds of money users. In brief banks operate by storing value in the form of money backed by debt. This account of banks is elaborated in the so-called credit theory of money (Bjerg 2014, 115-54). Classic references in this theory include Joseph Schumpeter (Schumpeter 1934, 70-74) and the lesser known Alfred Mitchell-Innes (Innes 1913, 1914) but in recent years the theory has been picked up and developed to account for the contemporary economy (Werner 2005; Ryan-Collins et al. 2011; Dyson and Jackson 2013; Huber 2014, 2017). The theory conceives of money as a particular form of debt, which is universally accepted in payments in the economy due to the exceptional status of the debtor. In our economy today, commercial banks have this position as universally accepted exceptional debtors, which is why their liabilities are conceived as an exceptional store of value.

We refer to this as the money manager perspective on money. The vantage point of this perspective is obviously the commercial bank but we may also include affiliated financial institutions such as the investment bank, the hedge fund, the pension fund, etc. that share the function of earning money by managing money. The money manager is primarily concerned about the ways that money functions as a store of value. The business model of a bank is to manage the interplay between money liabilities on the right hand side of the balance sheet and non-money assets on the left hand side. If bank liabilities lose their capacity as an exceptional store of value, banks will be the subject of different types of bank runs and they are eventually going to go out of business. The key to this business model is of course the earning of interests. Since bank liabilities are perceived as exceptional stores of value, money users accept to hold these at a relatively low rate of interest, while at the same time paying a higher interest rate on their loans to the bank.

The concerns of the money manager include questions such as: How do my bank account money retain their capacity as superior stores of value relative to cash and central bank reserve money? How much can I expand the balance sheet 
of my bank and thus the potential sources of income without jeopardizing the capacity of my liabilities as stores of value? How do I prevent the liabilities of other types of institutions to compete with the exceptional status of my liabilities as money? In the money manager perspective, the difference between different kinds of money is constituted by the fact that cash and central bank reserve money are non- or low-interest earning assets on the balance sheet of the bank, while bank account money are liabilities on the balance sheet where they emerge as counter items to loans, securities or other high- or medium-interest earning assets.

\section{The money maker perspective}

Now finally, what would we answer a twelve year old child asking the question: What is a krone? Again, we might begin with a simple answer: The krone is the currency of our country Denmark. If you go to another country such as for instance UK prices are listed in pounds and you have to pay in another kind of money. But perhaps the child insists and says: Yes, I know that, but I did not ask what is the krone, I asked what is a krone? By way of an answer, we might find a 1 krone coin in our wallet and point to it saying: This is $a$ krone. Since we know this child to be very smart (he understood how banks create money already when he was eight) we might add: Why are you asking such a simple question? And now the child says: I heard someone on the news talking about the cashless society and I was wondering that if we no longer have physical notes and coins, how do we know what a krone is?

What is at stake in this question is the function of money as a unit of account. Prices of commodities and services as well as outstanding debts within an economy are denominated in the currency of that economy. The currency thus functions as a numeraire allowing us to compare the value of different things and obligations by using a common monetary standard as bench mark. There are a number of different factors that determine, which currency counts as unit of account in an economy. Proponents of the so-called state theory of money point to the denomination of taxes as the most decisive factor (Bjerg 2014, 100-114). The classic reference for this theory is Georg Friedrich Knapp, who, among other things, served as a key inspiration for Keynes (Knapp 1924). The sovereign state has the power to determine the currency in which taxes and other debts to the state must be paid. It can also impose legal tender laws to extend this to the 
payment of other debts among citizens. This creates a constant and general demand for a particular kind of money in the economy, since most people will eventually need some of this money to pay their taxes and debts. The state then usually combines the power of taxation with a monopoly on money creation. It is then in a position to create the very same money that the citizens need in order to pay their taxes and debts. Once a particular currency is instituted as the general unit of account, this money automatically begins to function as a general medium of exchange and store of value in the economy.

The difference between the question: 'What is the krone?' and the question: 'What is a krone? is a difference between abstract and concrete unit of account. When we encounter prices denominated in kroner in the supermarket or debts denominated in kroner from the bank or the tax authorities, we encounter the krone as an abstract unit of account. But this function of money ultimately relies on the designation of a concrete unit of account. In order to price commodities, services and assets in terms of a currency, we need to know what is ultimately 'a Krone' or 'a Pound'. Among themselves money users may decide to use all kinds of things to settle payments. A car dealer may agree to accept two used cars in payment of one new car. A bank may agree to accept government bonds in payments of a debt. A farmer may pay his workers in produce and accommodation. But in order for the currency to function as a stable unit of account it has to legally designate some entity as the ultimate incarnation of money? The point here is not that money ultimately has to rely on gold or another commodity with intrinsic value. It is not even that money ultimately has to have a physical manifestation. There just has to be a final benchmark for the measurement of different prices. There has to be some entity, where exchange value and nominal value coincide by definition.

Our current money system relies on a monetary division of labour between the commercial banks, the central bank and the treasury. The treasury has the sovereign power of taxation. It accepts payment of taxes in three different kinds of money: cash, bank money and central bank money. This means that all of these monies principally count as concrete units of account. Since central bank reserve money is only accessible to banks, this payment option is closed to all other money users. Furthermore, the payment of taxes in cash is in most modern economy quite inconvenient and cumbersome. This means that commercial bank account money is the dominant concrete unit of account. 
The sovereign power of taxation exercised by the treasury is today used to support the creation of money exercised by commercial banks. There are, however, a couple of caveats in this monetary order. Money users still have the right to convert their bank money into cash in effect forcing the banks to pay their debt to the money users in notes and coins. Banks also have the right to demand their mutual credits settled in central bank reserve money. The role of the central bank is to prevent either of these two things from happening. The policy mandate of financial stability translates into the responsibility to maintain parity between cash, bank money and central bank reserve money thus maintaining the issuance and circulation of bank money at its nominal value. The sovereign state in the form of the treasury and the central bank take responsibility for the maintenance of the abstract unit of account. In turn, the de facto control of the concrete units of account has been outsourced to the commercial banks.

We refer to this kind of questioning into the nature of money as unit of account as the money maker perspective. Even though the state as incarnated in the government, the treasury and the central bank seems to have relinquished much of its control of the making of money, these institutions still constitute the natural vantage point of the money maker perspective. In so far as these institutions are not only incarnations of the state but also the representatives of the people of the democratic state, the money maker perspective is also the perspective of the citizen. While concrete money units of account are unevenly distributed among the money users in the economy, the currency as such is (or at least should be) a public common of all citizens regardless of their individual wealth. Even the debtor (or perhaps especially the debtor), who owns less than no money, has a legitimate interest in the currency in which his debt is denominated.

The primary concern of the money maker perspective is the question of sovereignty: Who controls the creation of money in the economy? What are the conditions for sovereign monetary policy? How does monetary policy correspond with the interests of the democratic state? What are the relations and boundaries between monetary and fiscal policy? In the money maker perspective, the crucial difference between the three kinds of money is that cash and central bank reserves are subject to the state monopoly on money creation, while bank money is issued at the behest of a particular kind of private companies. Another important difference is that electronic bank money and central bank reserve money can be interest bearing, while physical cash is by definition interest free. 


\section{What is CBDC?}

\section{Defining CBDC}

Having mapped out the constitution of our current monetary system, we now turn to Central Bank Digital Currency to see what the implementation of this new kind of money does to this constitution. The first task is simply to define what CBDC is. For this purpose we invoke the three questions posed at the beginning of the previous section:

What counts as this kind of money?

Who can use this kind of money?

Where does this kind of money come from?

In order to answer these questions, we take the definition provided by Barrdear and Kumhof of the Bank of England as our starting point:

By CBDC, we refer to a central bank granting universal, electronic, 24x7, national-currency-denominated and interest-bearing access to its balance sheet. (Barrdear and Kumhof 2016)

As CBDC we count deposit liabilities that are electronically registered on the central bank balance sheet. Access to these deposits is universal, which means that they can be held and used by principally all money users in the economy. The central bank issues these liabilities by crediting the accounts of money users. Summing up the issues of ontology, accessibility and supply, CBDC is electronic, universally accessible, central bank issued money.

This definition allows us to fit CBDC into the Venn diagram of the three existing forms of money (figure 2):

While each of the three existing forms of money is defined by lacking one of the features, CBDC is defined by no such lack. The diagram illustrates how CBDC combines all the three features of cash, bank money and central bank reserve money. This has profound implications for the discussion about the design and implementation of CBDC. It means that CBDC potentially competes with all of the existing forms of money. This competition automatically raises the 
question of whether CBDC should be a replacement or a mere supplement to any of the existing forms of money.

Figure 2: The features of CBDC

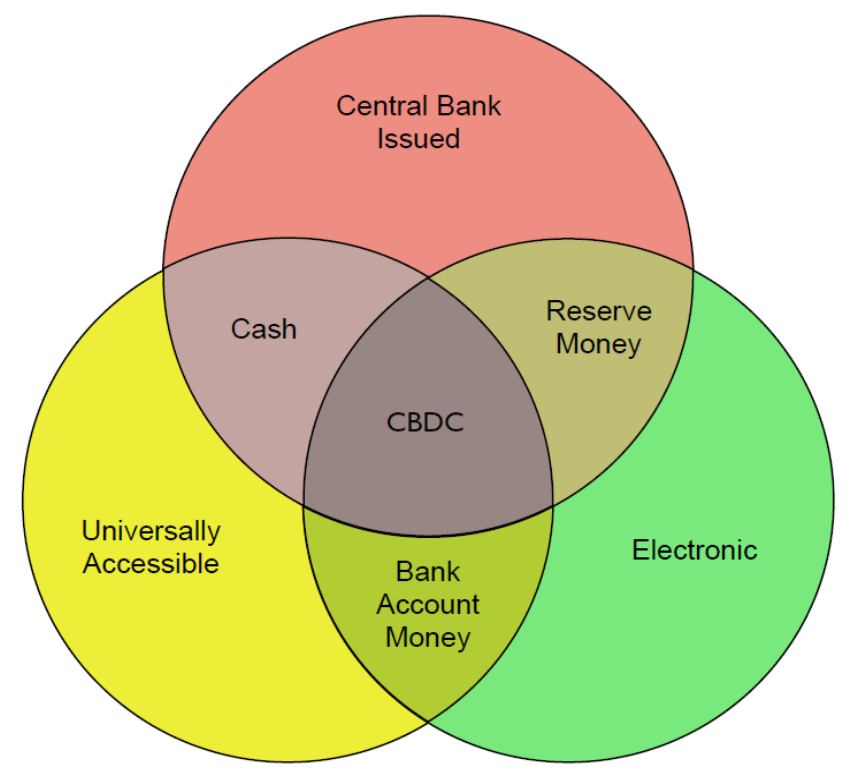

With regards to existing reserve money, this question is quite straightforward in so far as CBDC simply comes into being as a wider range of money users in the economy are provided with the opportunity to hold deposits with the central bank. The Barrdear and Kumhof definition takes it for granted that CBDC implementation implies universal access to the central bank balance sheet. It should be noted that it is indeed being discussed whether such access should be restricted to a more narrow range of non-bank financial firms (Broadbent 2016, 7; Cleland 2016, 5; Carney 2016, 6). In any case, a two-tier system with CBDC and existing central bank reserve money makes no sense, so we can rule out that option.

This leaves us with the questions regarding the relation between CBDC and the two other forms of money. The two crucial questions are simply:

- Should cash be abolished with the implementation of CBDC or should the two forms of money co-exist?

- Should bank money be abolished with the implementation of CBDC or should the two forms of money co-exist? 
Depending on the way that these two questions are answered, there are four different ways of combining $\mathrm{CBDC}$ with existing money each constituting a particular design model of the monetary system:

1) $\mathrm{CBDC}$ as complimentary to both cash and bank money

2) CBDC as a replacement for cash and complimentary to bank money

3) $\mathrm{CBDC}$ as a replacement for both cash and bank money

4) $\mathrm{CBCD}$ as complimentary to cash and a replacement for bank money

It may be tempting to list the pros and cons of each of these models in order to arrive at an evaluation of which one is the most optimal. Such an approach, however, would ignore the political nature of the monetary system. As we have seen in the previous section, the nature of money may be viewed from very different perspectives. Each of these perspectives comes with a particular set of concerns and interests. In his analysis of the history of debt, Graeber aptly notes how 'money has no essence. It's not "really" anything; therefore, its nature has always been and presumably always will be a matter of political contention' (Graeber 2011, 372). The ambivalent nature of money also plays into the discussion about changing the monetary system and implementing a new form of money such as CBDC. The way we think about money and imagine what money can and should do for us also frames our concerns and interests with respect to the design of a monetary system with CBDC.

\section{Electronic Cash, Universal Reserves, or Sovereign Account Money?}

In order to explore this issue we shall connect the three perspectives on money with the definition of CBDC. As we have seen, CBDC is defined by integrating the three features of existing money: electronic, universally accessible and central bank issued. Using the logic of the Venn diagram, we can also define CBDC in terms of each of the existing forms of money. These would be definitions that think of CBDC as an elaborated version of cash, bank money or central bank money:

1) $\mathrm{CBDC}$ is an electronic version of cash.

2) CBDC is a universally accessible version of central bank reserve money.

3) CBDC is a central bank issued version of commercial bank account money. 
From a purely logical perspective this may seem to be nothing but a play with words as there is no technical difference between these three definitions. They do not even add anything to the initial definition of CBDC. In the terminology of Kant, we would refer to them as analytical propositions that do nothing but recombine the inherent elements of the initial definitions of the different kinds of money. The significance of this play with words, however, emerges, when we move from the technical and logical and into the domain of politics. While each of the three definitions amount to the same basic features, they signify three different ways of thinking about CBDC in relation to existing forms of money. It makes a crucial difference for the political discussion about design and implementation, whether we think of CBDC as an elaborate version of cash, an elaborate version of central bank reserve money, or an elaborate version of commercial bank account money.

In order to think analytically about this issue, we shall make three propositions that guide the discussion of the subsequent sections of the paper:

- We propose to sum up the three definitions of CBDC in terms of three names that signify a particular way of thinking about money: electronic cash, universal reserves, or sovereign account money.

- We propose that the particular ways of thinking about money signified by the three names correspond to the three perspectives on money laid out in the previous section. This means that thinking about money from the money user perspective leads you to think about CBDC as electronic cash, thinking money from the money manager perspective leads you to think about CBDC as universal reserves, and thinking about CBDC from the money maker perspective leads you to think about CBDC as sovereign account money.

- We also propose that each of the three names corresponding to a particular perspective on money carries a predisposition towards a particular design of CBDC. Thinking about CBDC as electronic cash carries a predisposition towards a model where CBDC co-exists with cash and bank money. Thinking about CBDC as universal reserves carries a predisposition towards a model where cash is abolished and CBDC co-exist with bank money. Thinking about CBDC as sovereign account money branches into two models depending on whether it takes the central bank or the citizen as its vantage point. The former vantage point carries a predispo- 
sition towards a model where both cash and bank money is abolished and $\mathrm{CBDC}$ is the only form of money in circulation. The latter vantage point carries a predisposition towards a model where bank money is abolished and CBDC co-exists with cash.

These propositions are of course speculative deductions. Their purpose is to serve as the basis for the construction of three ideal typical scenarios with regards to the design and implementation of CBDC. The three ideal typical scenarios are summarized in table 1.

Table I: Ideal typical scenarios of CBDC

\begin{tabular}{|c|c|c|c|}
\hline & Money User & Money Manager & Money Maker \\
\hline Vantage point & consumer and firm & bank & citizen/central bank \\
\hline Primary function & medium of exchange & store of value & unit of account \\
\hline CBDC definition & electronic cash & universal reserves & $\begin{array}{l}\text { sovereign account } \\
\text { money }\end{array}$ \\
\hline Design model & $\begin{array}{l}+ \text { cash } \\
+ \text { bank money }\end{array}$ & $\begin{array}{l}\text { - cash } \\
+ \text { bank money }\end{array}$ & $\begin{array}{l}+ \text { cash / - cash } \\
\text { - bank money }\end{array}$ \\
\hline
\end{tabular}

In part 3, we shall be looking into each of these scenarios in order to unfold, how a particular view on money tends to point to a particular design model for CBDC. Furthermore, each of the design models carries with them a set of monetary policy implications and even contradictions. As we explore the different scenarios, we shall also be unfolding these implications and contradictions.

The primary design questions regard the status of cash and bank money that were listed previously: Should CBDC circulate together with cash or bank money, together with both, or together with none of them. We shall also be addressing two other questions, which are pertinent with regards to the design, implementation and subsequent management of CBDC. This first question concerns the introduction of new CBDC into the economy and the management of the total supply:

- Which agents should have access to buy CBDC directly from the central bank and in exchange for which kinds of assets?

The second question concerns the use of CBDC as a monetary policy tool:

- Should CBDC carry interest and should this interest be allowed to go into negative? 
As we are going to see, these questions are not entirely open as they are partially determined by the particular design model, which is chosen.

\section{The Monetary Policy Trilemma of CBDC}

Before moving into the exploration of each of the three scenarios, we provide a theoretical model to help us understand the monetary policy implications and contradictions of different design models of CBDC. The monetary dynamics of CBDC implementation may be understood in terms of an adapted version of the so-called monetary policy trilemma.

The original version of the monetary policy trilemma is based on ideas from Keynes (1930) subsequently elaborated by Mundell (1963) and Fleming (1962) and ultimately popularized by Obstfeld (1997), who coined the exact formulation of a trilemma. Obstfeld and Taylor provide the following definition:

The macroeconomic policy trilemma for open economies ... follows from a basic fact: An open capital market deprives a country's government of the ability simultaneously to target its exchange rate and to use monetary policy in pursuit of other economic objectives. (Obstfeld and Taylor 2002, 7)

Figure 3 below sums up the proposition of the trilemma, which is that any monetary policy authority (government or central bank) can simultaneously only pursue two out of the three policy objectives: monetary autonomy in the management of interest rates, currency exchange-rate management, and free capital mobility. 
Figure 3: The international monetary policy trilemma

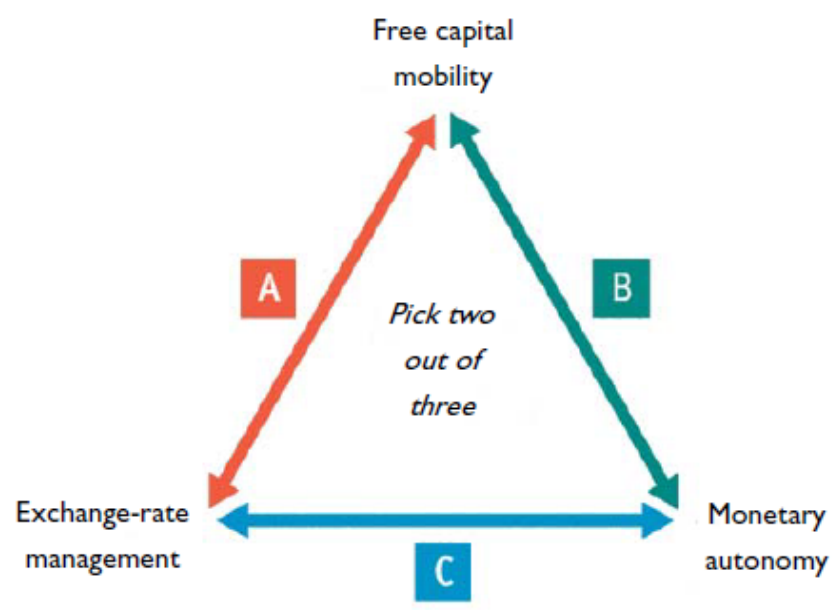

If a central bank pursues a pegged or just managed exchange rate policy against another currency, sets interest rates according to domestic monetary policy goals, while at the same time allowing money to flow in and out of the country, speculators/investors will take advantage of interest rate arbitrage opportunities between the two currency zones. This puts pressure on the currency and forces the central bank to do one of three things: (A) abandon a sovereign monetary policy and bring interest rates in line with that of the other currency, (B) allow the currency exchange to float, or (C) impose capital controls.

We can also understand these three options in terms of the three functions of money: If the central bank imposes capital controls $(\mathrm{C})$, it is restricting the use of the national money as a means of exchange. It can no longer be used to buy and sell foreign currency. If the central bank allows currency exchange rates to float (B), it is deteriorating the function of the national money as a secure store of value. And if the central bank abandons a sovereign monetary policy (A), it is giving up on the status of the currency as a unique unit of account.

The premise of the conventional monetary policy trilemma is the co-existence of two different currencies, which are created and managed by two difference central banks. This constitutes a situation of competition between two different kinds of money and two different money makers, which in turn potentially creates arbitrage opportunities for speculators/investors. In the context of our current discussion about $\mathrm{CBDC}$, the situation is analogous albeit different. If we begin with the current constitution of money, we also find a situation of competi- 
tion between two or three kinds of money and two different money makers. The different kinds of money are, however, not functionally equivalent in the same way as two different currencies. As we have discussed previously, cash, bank money and central bank reserve money are qualitatively different and they do not function as perfect substitutes for each other. This means that the competition between the different kinds of money is less perfect and much more restricted that the kind of competition underlying the conventional trilemma.

Given the fact that CBDC is both electronic and universally accessible, it is functionally equivalent to bank money. This brings about a kind of competition between central bank money and commercial bank money, which is comparable to the kind of competition between different currencies found in the conventional trilemma. The implementation of CBDC thus brings about the same kinds of contradictions that are found in the conventional trilemma. Let us see how we can translate the elements of the international monetary policy trilemma onto a domestic monetary system with CBDC. The translation is illustrated in figure 4.

- The conventional policy objective of exchange rate management between two currencies translates into the domestic policy objective of securing financial stability by maintaining parity between commercial bank money on the one hand and CBDC and cash on the other.

- The conventional policy objective of monetary autonomy in decisions on central bank interest rates translates into monetary sovereignty, which is the prerogative of the monetary authorities to use the creation of CBDC not only as a monetary policy tool to support commercial bank credit creation but also as a fiscal policy tool to stimulate the general economy. The abandonment of monetary sovereignty means that commercial banks are the primary drivers of money creation.

- The conventional policy objective of free capital mobility translates into free convertibility between commercial bank money and central bank money. We may understand the implementation of CBDC as the introduction of such convertibility. With universal access to the central bank balance sheet, ordinary money now for the first time have the option to choose between holding electronic money with the central bank or with commercial banks. 
Figure 4: The domestic monetary policy trilemma

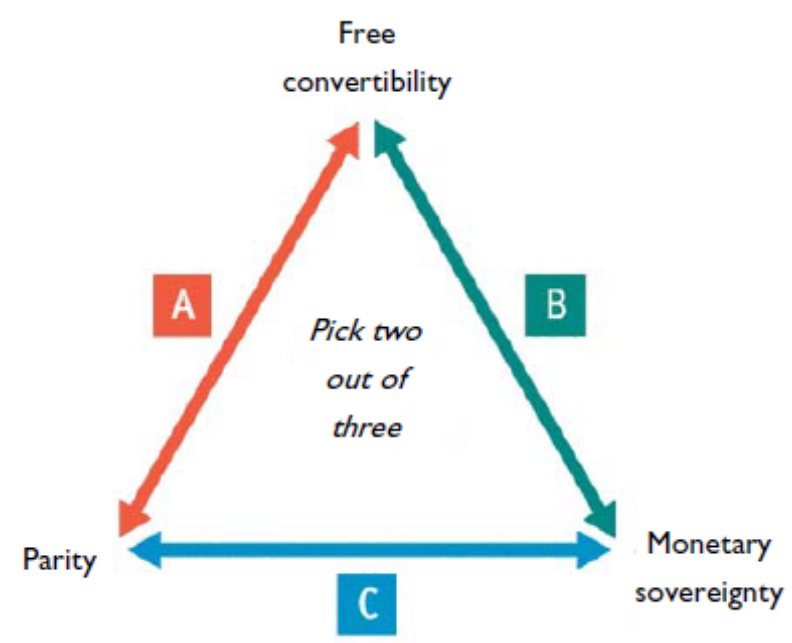

Our proposition is that a monetary system with two competing money creators, the central bank and the commercial banking sector, can simultaneously only pursue two out of these three policy objectives. Since central banks have not hitherto been able to create electronic money, ordinary money users have had only a limited and inconvenient opportunity for convertibility between commercial bank money and central bank money. Furthermore, central banks have also had only limited opportunity to supply money directly into the economy to provide fiscal stimulus. This means that the domestic monetary policy trilemma has been solved by some version of $(\mathrm{C})$ and $(\mathrm{A})$. The overall priority in contemporary monetary policy seems to be the maintenance of parity between commercial bank deposit money and the two forms of central bank money. Central banks seem to have been content with giving up both the money users' opportunity for convertibility as well as their own monetary sovereignty to achieve this objective.

The implementation of CBDC is the equivalent of a relaxation of capital controls as money users are now granted free convertibility as well as an opportunity for sovereign money creation as fiscal stimulus. In the following sections, we shall explore possible solutions to the contradictions that such opportunities bring about. 


\section{The Money User Scenario}

\section{CBDC as Electronic Cash}

Should the Riksbank issue electronic means of payment in the same way as we now issue cash? This is a natural question for a central bank, as technological advances create new opportunities, as the printing press once upon a time made it possible to print banknotes. Banknotes were a complement to the minted coins, and are so today too. Similarly, an electronic means of payment, say an e-krona, could be a complement to physical cash. This is the question I intend to discuss today. The question is particularly relevant for us in Sweden, as cash is being used to a declining extent and is sometimes difficult to get hold of. (Skingsley 2016, 1)

This is how Cecilia Skingsley of the Swedish Riksbank presents the question of CBDC. The quote provides an illustration of the conception of CBDC as an electronic form of cash. The stated reason for the Riksbank's interest in CBDC is a rapidly declining use of cash as a means of payment in the Swedish economy. This means that 'cash is no longer as easily accessible as before' and 'the general public finds it more difficult to get hold of money issued by the Riksbank' (Skingsley 2016, 1). We see here, how Skingsley represents the perspective and concerns of the 'general public' as money users.

The key concern is that if the development of the payment system is entirely determined by 'market participants', some groups of money users, including 'many consumers ... small companies and local clubs,' may lose 'access to basic payment services, including cash. In situations where the market is not able to supply basic payment services, it is the task of the state to ensure that everyone has access to such services' (Skingsley 2016, 6). It is, in other words, the responsibility of the central bank to secure the financial inclusion of all money users.

Another set of concerns regarding the declining availability of cash include issues of anonymity, security and resilience:

One cannot get away from the fact that cash has properties that electronic payment services lack. Will this mean that we lose a means of payment that cannot be directly replaced with something else? Cash can be handed over regardless of access to electricity or the internet. Cash payments are anony- 
mous. A payment can be made in cash without involving the banks. Even if cash is not used on a daily basis, it comprises a backup option in certain crisis situations. (Skingsley 2016, 6)

Again, we see how these concerns emerge from the money user perspective. This perspective also plays out in Skingsley's account of the invention of money in terms of the classical story of barter:

The barter system is, in my view, the most important innovation of all time.

The reason I think this is that trade is a necessary condition for welfare.

There is hardly anyone who grows all their own food. Nor do we mine iron ore and grow rubber trees to be able to build our own car. Trade allows us to specialize in making goods and services that other people want and which therefore have a value. The carpenter does woodwork, the dentist fixes teeth, the author writes books and so on. In the beginning, we traded with one another simply by swapping goods and services. However, the barter system is not practical, as it means you have to find someone who has what you want and who also wants what you have. /.../ Money plays an important role in reducing transaction costs and this is why money is the second most important innovation in the history of the world. (Skingsley 2016, 2)

The design model proposed by the Riksbank as represented by Skingsley is one in which CBDC is complementary to both cash and bank money. While the option of replacing bank money does not even seem to be on the table, she explicitly states that: 'If the Riksbank chooses to issue e-krona, it would not be to replace cash, but so that the e-krona can act as a complement to cash' (Skingsley 2016, 7). In so far as the Riksbank's primary concern seems to be to represent the interests of the general public as money users, this design model makes perfect sense as it provides the money users with the widest scope of choice in terms of money and payment options.

The point of this review of the speech from the Riksbank is not to suggest that it represents the money user perspective exclusively. In its entirety, the speech includes a range of other viewpoints and reflections that should be associated with the two other perspectives. The same goes for the other speeches and text that we shall be quoting in our exposition of the other scenarios. 


\section{Sacrificing Sovereignty to Save Parity}

By allowing money users the opportunity to hold money in the form of bank deposit money, cash or CBDC, as well as the option to freely convert between these kinds of money, the money user scenario opens up the dynamics of the monetary policy trilemma.

From the history of economics, we know the phrase 'bad money drives out good' also referred to as Gresham's law. Gresham's law was originally formulated in the context of precious metals money and it refers to a situation, where different forms of money circulate at the same nominal value, while there is a discrepancy between their respective commodity values. This may occur in a system based on a simultaneous circulation of gold and silver coins denominated at a certain fixed price ratio. If the market price of gold begins to increase relative to silver, the spread between market price and nominal value will also become smaller for gold coins than for silver coins. In such a situation, the 'bad' silver money will be preferred as medium of exchange and debt settlement thus 'driving out' of circulation the 'good' gold money, which is hoarded and used as a store of value.

The essence of central banks' responsibility for financial stability is the maintenance of parity between the different forms of money in circulation. Parity management amounts to keeping the mechanisms of Gresham's law in check. Skingsley touches upon this issue as she notes how 'the special thing about central bank money is that it has no nominal credit risk, as it stands for a claim on the central bank, which cannot go bankrupt.' In contrast, 'the commercial bank money does entail a risk - even if the risk is slight. If the bank fails, you may not be able to redeem your entire claim on the bank from its bankruptcy estate' (Skingsley 2016, 3-4). The introduction of CBDC poses a challenge to parity. If money users have access to risk free central bank money, why would they hold risky commercial bank money? The risk to financial stability is, in other words, that 'good' CBDC drives out 'bad' commercial bank deposit money. Such a break of parity is what we refer to as a 'run on the bank'.

Assuming that the central bank wants to maintain the policy objective of parity, it has to give up monetary sovereignty by putting its monetary policy solely in the service of defending parity. This is option (A) in the policy trilemma. We shall explore the implications of this option. 
There are four main channels through which the central bank in collaboration with the treasury maintains parity. All of these channels are already in play today, but they may be pushed to further extremes in a system with CBDC. The first is by allowing citizens to carry out their financial transactions with the government in commercial bank money. If the treasury accepts bank money in payments of taxes at its nominal value, this provides a form of 'tax standard' on this kind of money. If money users start to worry about the credit risk of commercial bank money, the treasury provides a guarantee that the money users can always redeem this 'bad money' at the nominal value. In a system with CBDC, the treasury would thus still give the citizens the option of paying taxes in commercial bank money and the government may even choose to pay out salaries to public employees in bank money to support parity.

The second channel is the lender (or buyer) of last resort facility. The purpose of this facility today is to prevent liquidity crises by providing commercial banks with the opportunity to borrow or buy central bank reserves or cash in exchange for government bonds or other low risk securities. This gives the banks liquidity and flexibility in their asset management, which allows them to respond to shifting demands from money users for different kinds of money. In a system with $\mathrm{CBDC}$, the banks would retain this opportunity. If money users were to suddenly demand conversion of their bank deposit money into CBDC in excess of the bank's stock of CBDC, the banks would be able to turn around to the central bank and convert their assets into CBDC, which would then subsequently be used to redeem the deposit liabilities of the banks. In extreme cases, the use of this channel in the defense of parity may face the central bank with some difficult questions as to the kind of assets it would be willing to accept in exchange or as collateral for the provision of CBDC to the banks. This issue shall be further explored in the next section.

The third channel is the depositor insurance, which guarantees commercial bank money up to a certain amount (in Europe $€ 100.000$ ) in the case of bank defaults. While such insurance is today initially underwritten by the collective of commercial banks, history seems to have established the expectation that in the case of a major systemic crisis, the central bank will ultimately step in to guarantee the guarantee. In a system with CBDC, the central bank will provide a similar guarantee by de facto promising to take over the deposit liabilities of insolvent banks and redeem them in CBDC. Such a promise would function to allevi- 
ate credit risk concerns among money users holding bank money and thereby serve to maintain parity.

\section{The Question of Interest}

The fourth channel, which would in practice function as the first line of defense against the challenge to parity, is the monetary policy tool of interests on CBDC. While the first three channels aim to defend parity against the logic of Gresham's Law by making commercial bank money as 'good' as CBDC, this fourth channel provides a similar defense by making CBDC as 'bad' as commercial bank money. Skingsley lays out the problem like this:

If the Riksbank launches an e-krona with a positive interest rate, it can in some situations be very attractive for both the general public and companies to convert their account balances in the banks to e-krona with the Riksbank. (Skingsley 2016, 9)

The difference between electronic CBDC and physical cash is not merely one of convenience and functionality. While cash is by definition interest free, CBDC can be interest bearing. This provides the central bank with a tool to defend parity. In order to compensate money users for taking the credit risk of holding bank money instead of risk free CBDC, the central bank must set the interest rate on CBDC below the interest rate on bank money. This is not unlike the way that the central bank today adjusts the interest rate on central bank reserves. But still the central bank finds itself having to choose between the defense of parity and the use of monetary policy for other purposes.

If the central bank is committed to maintaining an interest rate on CBDC, which is lower than the interest rate on deposits, and perhaps even committed to widening the spread, if the general trust in the solvency of the banks is deteriorating, then the commercial banks' decisions on their deposit rates effectively set the upper bound of the CBDC interest rate and thus also a limit the scope of central bank monetary policy. What would happen, if the central bank wanted to raise interest rates in order to combat inflation, while the commercial banks insisted on lowering deposit rates to increase their profit margins? Would the central bank be willing to jeopardize parity to defeat the commercial banks in such a monetary policy chicken game? And what if a central bank committed to currency exchange rate management see the central bank of its benchmark currency 
raise interest rates, while its domestic banks insists on lowering their deposit rates. In such a situation, the central bank would find itself squeezed between the two policy trilemmas as it would have to choose between maintaining a currency peg or maintaining parity.

An even more pertinent problem in the current economic climate of historically low interest rates and a perceived risk of deflation is constituted by the lower bound on interest rates. The fact that money users may choose not only between bank money and CBDC but also cash institutes a de facto zero lower bound on interest rates. Even if it is technically possible to allow interest rates on CBDC to move below zero, such a move would soon compel money users to convert into interest free cash.

In a situation with declining bank money deposit rates, the central bank could find itself stuck and unable to adjust CBDC interest rates either up or down. Some central banks seem to already find themselves in this situation, where the commitment to parity has stifled their opportunity for sovereign monetary policy. The implementation of CBDC together with both cash and bank money would not relieve but probably rather intensify this deadlock. Just like one of the solutions to the conventional policy trilemma is to leave the monetary policy initiative to competing money makers in the form of a foreign central bank, the commitment to parity in the domestic monetary policy trilemma leaves the monetary policy initiative to competing money makers in the form of commercial banks. This is a theme that we shall be further expanding on in the following section.

The conclusion to the current section is that even if the Swedish Riksbank or another central bank decides to afford money users a maximum availability of payment and money options by designing a system where CBDC co-exists with both cash and bank money, it may find itself having to pay the price of not being able to use monetary policy for anything else than defending the parity between the three kinds of money. 


\section{The Money Manager Scenario}

\section{CBDC as Universal Reserves}

In the extreme, a DL [distributed ledger] for everyone could open the possibility of creating a central bank digital currency. On some levels this is appealing. For example it would mean people have direct access to the ultimate risk-free asset. In its extreme form, it could fundamentally and perhaps abruptly reshape banking. However, were it to co-exist with the current banking model, it could exacerbate liquidity risk by lowering the frictions involved in running to central bank money. These questions and others are why these topics are being examined as part of the Bank's research agenda, with the prospect of a central bank digital currency for the UK, in my view, still some way off. We will work to make payments easier, and though cash may no longer be the king it once was, its reign will endure for some time.

(Carney 2016, 8-9)

This quote is from a speech by the Governor of the Bank of England, Mark Carney. While Carney raises some of the same issues that we have seen in the speech by Skingsley, the quote is also suited to illustrate a slightly different type of concerns regarding the implementation of CBDC.

Carney refers to CBDC as 'the ultimate risk-free asset'. This conception gives primacy to the function of money as a store of value. Having noted how 'direct access' to this kind of money is 'appealing' to the ordinary money user in the form of the 'people', he shifts the perspective to point out how the co-existence of CBDC and bank money would pose a risk to the current banking model. If money users are given the option to choose between holding electronic money in the central bank and in a commercial bank they may, in other words, choose the former since CBDC is a superior store of value. While other parts of Carney's speech also include other perspectives on CBDC, this particular passage represents the concerns of the money manager. For the money users, access to risk-free CBDC increase their scope of choice, convenience and security, but for money managers such as commercial banks, CBDC constitutes competition and a threat to their business model. It is from this latter perspective that universally accessible CBDC appears to be 'extreme' since it might 'abruptly reshape banking.' 
In the scenario proposed by Skingsley, CBDC is complementary to both cash and bank deposit money. Carney is much less explicit about this but his juxtaposition between CBDC as being 'still some way off' and the prediction that the 'reign' of cash 'will endure for some time' seems to suggest that the two are conceived as alternatives. This is also how we may interpret the following quote from a speech by Deputy Governor for Monetary Policy at the Bank of England, Ben Broadbent:

As far as its economic effects are concerned, my guess is that much would depend on how exactly a central bank digital currency (CBDC) is designed and in particular the extent to which it competes with the main form of money in the economy, commercial bank deposits. As individuals, we already have the ability to hold claims on the central bank, in the form of physical cash. If all a CBDC did was to substitute for cash - if it bore no interest and came without any of the extra services we get with bank accounts - people would probably still want to keep most of their money in commercial banks. (Broadbent 2016, 3)

In addition to the positioning of CBDC as a 'substitute for cash', it is also worth remarking the prediction that money users would still keep their money in the bank if CBDC came without interest and 'extra services'. Given the current situation, where commercial bank deposit rates are close to if not outright zero and a substantial part of bank profits are derived from fees accrued from customers, it seems rather optimistic to base monetary policy on such a prediction. An alternative scenario is that when conventional banks lose their monopoly on the issuance of electronic money, the banking sector would be unbundled and banks would find themselves in even competition with peer-to-peer lending companies, unconventional payment service providers and other non-bank businesses in the provision of 'extra services' to money users (see Ketterer et al. 2016).

As we have discussed previously, the money manager perspective is associated with the credit theory of money that explains how money is created when bank's issue new loans. In Broadbent's speech, we find a concern about CBDC that is derived from some version of this theory of money:

$[T]$ aking deposits away from banks could impair their ability to make the loans in the first place. Banks would be more reliant on wholesale markets, a source of funding that didn't prove particularly stable during the crisis, and could reduce their lending to the real economy as a result. 
This is the really main point I want to get across. Some suggest that central banks will have to issue their own digital currency - i.e. to supply central bank money more widely, via some generalised distributed ledger - to meet a "competitive threat" from private-sector rivals. I suspect a more important issue for central banks considering such a move will be what it might mean for the funding of banks and the supply of credit. (Broadbent 2016, 3)

The concern here is that the implementation of CBDC would impair the commercial bank's ability to create new money and lend it into 'the real econo$\mathrm{my}^{\prime}$. While this concern is clearly valid, it is worth considering whether the problem is one of the supply of money, as suggested by Broadbent, or perhaps rather one of demand for money. Before delving further into this question, we shall conceptualize the concerns of the money manager in terms of the monetary policy trilemma.

\section{Making Good Money Worse}

From the money manager perspective, the prospect of CBDC being 'still some way off' thus provides some degree of comfort. It allows the banks to maintain their current business model and it allows the central bank to stick with option $\mathrm{C}$ in the policy trilemma. But if CBDC were to be implemented, the concerns of the money manager could be partially met by using it as an opportunity to phase out cash. This would effectively move the zero lower bound, which is currently preventing interest rates from moving far into negative territory. Such line of reasoning is illustrated by the following quote from Chief Economist at the Bank of England, Andrew Haldane:

One interesting solution, then, would be to maintain the principle of a government-backed currency, but have it issued in an electronic rather than paper form. This would preserve the social convention of a state-issued unit of account and medium of exchange, albeit with currency now held in digital rather than physical wallets. But it would allow negative interest rates to be levied on currency easily and speedily, so relaxing the ZLB [Zero Lower Bound] constraint. (Haldane 2015, 11)

In the previous section, we have already seen how the co-existence of CBDC and bank money forces the central bank to dedicate all of its monetary policy to the maintenance of parity by keeping an interest margin between CBDC and bank money corresponding to the difference in their perceived credit risk (option 
A). The implementation of CBDC as a substitute for cash expands the scope of monetary policy since money users no longer have an interest free option to hold money. Cash is the weakest link in the central bank line of defense of parity. With cash removed, the central bank is now able to combat bank runs by increasing negative interest rates on CBDC. This removes the risk of 'bad' commercial bank deposit money driving out 'good' central bank reserve money since the central bank can always make CBDC 'worse' than bank money.

From the money manager perspective, this design model also opens up additional prospects. There are the immediate benefits of saving some operational costs from not having to handle cash, which has to be taken in and paid out to customers. Along similar lines, banks would also have to worry less about bank robberies if there was no cash to rob. But a much more significant prospect has to do with increasing revenue rather than just saving costs. In the current environment of low interest rates, it is difficult for commercial banks to make a profit on the interest spread between deposits and loans. If the central bank is willing to increase negative interest rates on CBDC, it opens up the space for banks to push this development and thus to make money not only by charging interests on loans but also charging negative interest rates on deposits. They can, in other words, innovate their business model by not only making money from borrowers but also from depositors.

Charging negative interest rates on either bank money or CBDC is essentially a form of money destruction. If the central bank imposes a 5 percent negative interest rate on CBDC it is decreasing the supply of CBDC by 5 percent per year. A scenario, where the central bank is forced to charge negative interest rates on $\mathrm{CBDC}$ in order to defend parity with bank money, it is thus essentially destroying CBDC held by money users to maintain the commercial banks' ability to create new bank money.

\section{Money Supply or Money Demand}

When Barrdear and Kumhof of the Bank of England define CBDC as 'a central bank ... granting universal ... access to its balance sheet' (see previous quote) they are only referring to the liability side of the central bank balance sheet. CBDC allows money users to hold the liabilities of the central bank, which puts them on par with banks. Today, however, banks are not only privileged by hav- 
ing access to the liability side of central bank balance sheets. They also enjoy a privileged access to the asset side of central bank balance sheet in so far as they have the exclusive right to initiate the buying or selling of financial securities in exchange for central bank reserve money. This typically happens through socalled repurchase agreements or repos. The most usual form of security to be traded between central banks and commercial banks is government bonds. When commercial banks are net-sellers of financial securities to the central bank, the supply of central bank reserve money is increased. This is what happens in ordinary open market operations and in more extreme measures in Quantitative Easing. An implementation of $\mathrm{CBDC}$ with universal access to the liability side of central bank balance sheets immediately raises the question if all money users should also have the opportunity to initiate an increase in the supply of CBDC by demanding to sell securities to the central bank. The question is, in other words, if universal access to the central bank balance sheet should be extended to the asset side.

There are three general options of how to design a CBDC model with regards to this question: 1) Only banks are granted the opportunity to exchange CBDC for financial securities with the central bank. This is the way it already works with central bank reserve money today. 2) All money users are granted the opportunity to buy and sell CBDC for financial securities at the central bank. 3) The central bank refrains from expanding or contracting the money supply through open market selling or purchasing of financial securities and no one is granted the opportunity to trade directly with the central bank. The choice between these three different designs is no insignificant matter. It has profound implications for the management of the supply of money. The fundamental question in this regard is whether the size of the total amount of money in the economy shall be determined by demand or supply.

We normally refer to the amount of money in the economy as the 'money supply'. In the context of our current money system, this concept is misleading as money today is created in response to the demand for credit. Since banks can create new money by expanding their balance sheets, only under very special circumstances are they constrained by supply. When potential borrowers are rejected it is rarely due to a lack of money but rather because they are not regarded as credit worthy by the bank. It would thus be more appropriate to speak of the 'money demand' rather than the 'money supply'. 
If $\mathrm{CBDC}$ is designed according to the perspective of the money manager, banks would maintain their exclusive privilege to trade securities for central bank money directly with the central bank. The central bank creates CBDC in response to demands from commercial banks requesting to buy CBDC. Commercial banks in turn respond to demands from money users wanting to hold CBDC instead of bank account money or cash. Commercial banks thus retain their role as the first creators of new money through their lending activity, which is determined by the demand for credit in the economy. Once the aggregate supply of money has been expanded by the commercial banks, its composition of CBDC and bank account money may be altered by the preferences of the money users. When commercial banks purchase CBDC from the central bank to meet demands from customers, it does not change the aggregate supply of money. When a bank pays out an amount of CBDC to a customer it simultaneously cancels out an equivalent amount of bank account money. If, however, the commercial bank purchases CBDC from the central bank and holds this money itself instead of paying it out to customers, it would amount to an increase in the supply of money. In essence, CBDC would be introduced into the economy in similar fashion as cash is supplied today.

At first sight it might seem as if such a model would put restrictions on the commercial banks' capacity to provide credit and lending into the economy. This was also the concern raised by Broadbent in the above. Since banks are obliged to meet money users' demand for conversion of bank money into CBDC, they have to make sure that their stock of CBDC or at least their stock of liquid securities that are easily convertible into CBDC, is large enough to meet such a potential demand. If banks do not have enough CBDC they could be forced to reject potential borrowers.

This concern, however, rests on confusion between supply and demand. If central banks are committed to the maintenance of parity they are eo ipso also committed to the provision of enough CBDC to meet money users' demand for conversion of bank money into CBDC. If banks do not have enough CBDC on their balance sheet to meet demands for conversion, they simply just turn to the central bank and exchange some of their assets for CBDC. The creation of bank money and credit is not restricted by supply and thus 'taking deposits away from banks' does not, as suggested by Broadbent, 'impair their ability to make ... loans in the first place.' 
This does not mean that the design model with CBDC and bank money is without problems. But the risk is not, that banks are unable to make enough bank money, but rather that they are incited to make too many. If banks retain the opportunity to increase the total money supply through their issuance of new credit while the composition of the money supply in terms of bank account money, and CBDC is subsequently determined by the preferences of money users, the central bank may find itself faced with some difficult questions. In the aftermath of the financial crisis and under existing Quantitative Easing programs, central banks have increased the volume of open market operations and expanded their asset portfolio to comprise other kinds of securities than government bonds. This includes corporate bonds, mortgage bonds and even in some cases equity. Such increased engagement in financial markets has already posed a series of fundamental questions about the role and mandate of central banks: Which types of risks should a central bank take on? To what extent should it mobilize its balance sheet to interfere with the pricing of securities in the market? Should central banks shield private banks from losses and default by absorbing risky assets? In a model, where CBDC is implemented as complementary to bank account money, these questions are going to become even more pressing and pertinent.

If the central bank remains committed to supply whatever amount of CBDC is demanded first by money users and then by commercial banks, the central bank may ultimately find itself unable to decide, how many securities it wants to buy and hold. This is conceivable in a kind of digital bank run scenario, where money users decide that CBDC are more attractive than bank account money and they turn to their bank for conversion. In order to meet such demand, the bank turns to the central bank to exchange securities for CBDC. The central bank would have to accept this proposition and take on the role of 'buyer of last resort' in order to maintain financial stability. But what happens when the commercial bank's stock of high-grade assets has been exhausted and money users' demand for CBDC is still not satisfied? The central bank may find itself taking over significant amounts of bad debts taken on by the banks. And how should the assets exchanged for CBDC be priced in the first place?

The central bank is an atypical agent in the financial market: It is ultimately obliged to buy. It can create its own money. And it is not trading to make a profit. This means that its trading engagement will have profound effects on the pricing mechanisms of the market. This is already happening under current QE 
schemes, which have the effect of inflating asset prices as central banks are seemingly insatiable net buyers in the market. Furthermore, we have also seen central banks buying so-called 'troubled assets' from commercial banks as part of various bail-out schemes thus absorbing losses originally incurred by private corporations. An implementation of CBDC alongside bank account money will just exacerbate these effects.

A further scenario is that commercial banks take advantage of the central bank's commitment to meet demands for CBDC by exchanging them for securities. We might see a repeat of the US mortgage crisis, where banks made a profit by extending excessive amounts of risky loans. These risks were then subsequently offloaded from the banks' balance sheet by being securitized and sold. Rather than selling such securities to unknowing investors, which happened in the build up to the crisis, the banks may now simply sell them to the central bank in exchange for CBDC.

Several central banks are currently engaged in QE schemes. These schemes are supply driven in the sense that the central banks decide the amount of new reserve money that they want to supply to the banking system by purchasing financial assets. In a money system with CBDC circulating alongside bank account money, central banks may find themselves in demand driven QE schemes, where the amount of new CBDC to be supplied is determined by demands from commercial banks and money users. The problem is not that banks have exclusive access to the asset side of the central bank balance sheet by being able to buy CBDC directly from the central bank. Expanding this access to all money users would merely exacerbate the problem. In the following, we shall be looking into a design model, where neither banks nor money users have access to this kind of direct exchange with the central bank. In this model, the money supply is thus truly driven by supply. 


\section{The Money Maker Scenario}

\section{CBDC as Sovereign Account Money}

Money is an instrument of exerting power, comparable only to legal command power backed by force. The right to be a creator and first user of money gives power and privilege over all subsequent users. In modern societies as much as in traditional ones, such power and privilege must not be private, but a sovereign prerogative, preferably under conditions of separation of powers and the liberal rule of law.

Control of the money of a realm has always been an element of sovereign rule, much as lawmaking, the judiciary, taxation and the use of force. The monetary prerogative includes the sovereign rights of determining the currency (a country's monetary unit of account), creating the money denominated in that currency (the official means of payment), and benefiting from the seigniorage thereof by spending or lending the money and thus releasing it into circulation. The constitutional dimension of money must not be disregarded, either in terms of legitimacy and state law, or in terms of economic functionality. (Huber 2017, 3)

This is not a quote from a central banker but from Professor Joseph Huber, who is one of the first advocates of the idea of central banks creating digital cash (Huber and Robertson 2000). The quote illustrates an approach to money and money creation, which is structured by legal concerns regarding sovereignty and legitimacy. In this approach, the creation of money is ultimately a constitutional matter (see also Binswanger, Huber, and Mastronardi 2012; Huber 2014). This implies that the creation of the nation's money supply is a prerogative of the sovereign state.

In the first sentence of his book, Huber writes: 'This book aims to make people aware of the central position the monetary system occupies in today's highly monetarized and financialized economies' (Huber 2017, 1). In contrast to Skingsley's invocation of 'the general public' as money users, which we encountered previously, Huber addresses 'people' as citizens of a democratic state with a legitimate interest in the constitution of the monetary system. The purpose of the implementation of CBDC, according to Huber, is to reinstate the central bank as 
the sovereign money maker. In so far as the central bank is a public institution, it is the representative of the people. Huber is thus ultimately addressing people as money makers.

According to Huber, monetary sovereignty includes:

1. Determining the currency of the realm, the common unit of account

2. Creating and issuing the money, the regular official means of payment denominated in that currency, and

3. Taking the benefit from money creation, the seigniorage. (Huber 2017, 144)

The order of this list is not accidental. The determination of the currency is the most important as it is the prerequisite for the second point, which is the prerequisite for the third. The list thus foregrounds the function of money as unit of account. Huber's understanding of our current money system partly relies on the credit theory, which we also found in the money manager perspective. At the same time, Huber insists that the credit theory should be combined with the state theory in order to understand, how banks can only create money as long as the state allows their credit to count as the unit of account (Huber 2017, 92-97). As we have seen, this happens first and foremost as the state accepts bank money in the payment of taxes. This institutes bank money as a concrete unit of account of the currency.

For Huber the state theory of money is not only applicable in the analysis of the money system. It also serves as a normative theory about the way that the money system ought to function. The key feature of the CBDC design model, which follows from the money maker perspective, is the abolition of bank credit as money. In this model, there is a complete identity between the entity, which is responsible for the abstract unit of account, and the entity, which is the creator of the concrete unit of account. While banks would retain their ability to create credit, just like any other business or individual in the economy, there would be no state or central bank guarantee that this credit counts as money and circulates at par in the economy.

The CBDC design model of the money maker scenario solves the monetary policy trilemma by abandoning the responsibility to maintain parity between central bank money and commercial bank money. This is solution (B) in the triangle. In return, the central bank regains monetary sovereignty and the opportunity to use monetary policy for other purposes than providing support for the 
creation of bank money. Dyson and Hodgson from the UK monetary reform organization, Positive Money, provides a list of such opportunities including the provision of fiscal stimulus to the non-financial economy through money creation (Helicopter Money) and public recapture of seigniorage profits (Dyson and Hodgson 2016, 6-14).

\section{Integration of Monetary and Fiscal Policy}

The most immediate consequence of the implementation of a CBDC design model without bank money would be a tremendous simplification of the monetary system. Many of the questions and challenges that would have to be addressed and solved in a model where CBDC and bank money co-exist simply vanishes.

First, the money supply would actually become a money supply. As we have seen, the total stock of money under the current monetary system is best referred to as the 'money demand', since it is governed by demand and only in extreme cases restricted by supply. In a CBDC design model without bank money, the central bank would be the only source of the supply of money and would thus be in a sovereign position to increase or decrease the stock of money by adjusting the supply.

Second, central bank monetary policy would no longer have to rely on the assumption of an indirect causality between central bank reserve interest rate adjustments and commercial bank money creation, which is assumed to be mediated by complex transmission effects. In a CBDC design model without bank money, the payment of interests on CBDC deposits would effectively be money creation. When the central bank credits the CBDC accounts of money users, because they have accrued interests, it simply creates money. Should the central bank decide to impose negative interest rates on $\mathrm{CBDC}$, the debiting of these interests would amount to a destruction of money. The payment or collection of positive or negative interests on $\mathrm{CBDC}$ is, in other words, one of the channels through which the central bank can increase or decrease the money supply.

Third, the distinction between monetary and fiscal policy interventions in the economy would disappear. The implementation of CBDC without bank money does not necessarily mean that the current institutional division between decisions on monetary policy and fiscal policy is abandoned (Huber 2017, 146-51; 
Jackson and Dyson 2012, 203-10). Decisions on how much money should be created could still be made by an independent central bank on the basis of a certain monetary policy mandate. And decisions on how to spend newly created money would still be made by an elected parliament based on fiscal policy preferences. The novelty is that the even monetary policy decisions made by the central bank would have immediate fiscal implications. If the central bank pays interest on CBDC it is effectively paying a kind of social benefit to money holders. If it charges negative interest rates on CBDC it is levying a tax on money. Besides interests on $\mathrm{CBDC}$ there are a number of other channels through which the central bank can introduce new CBDC into the economy (Huber 2017, 160-63; Jackson and Dyson 2012, 211-18). If its monetary policy mandate requires an expansion of the money supply, the central bank can simply credit the treasury's CBDC account and thus make new money available for public investment and spending. The central bank can also simply credit the CBDC accounts of all citizens in the country with an equal amount. Since new CBDC is in both of these cases immediately distributed to money users, it is impossible to distinguish between their monetary and fiscal policy effects.

Fourth, the decision on whom to allow the privilege of exchanging financial assets for CBDC directly with the central bank has much less significance for monetary policy. In addition to the above mentioned channels for the introduction of new CBDC into the economy, the central bank could also make an amount of new CBDC available for banks and other financial intermediaries to borrow, who are then able to expand their lending into the economy. This would probably remain a more pure form of monetary policy intervention. In contrast to the CBDC design model with bank money, the central bank is now in a much better position to make a sovereign decision on how much new money it wants to lend into the economy and then subsequently decide to whom it wants to lend and what kind of assets it will accept as collateral. Since the central bank is no longer compelled to defend parity, commercial banks are no longer in a position to drive the money supply through a demand for conversion of financial securities into CBDC. 
What about Cash?

As introduced already in section three, the money maker scenario branches off into two different design models: 3) $\mathrm{CBDC}$ as a replacement for both cash and bank money, or 4) CBDC as complimentary to cash and a replacement for bank money. The first thing to note in the comparison between these two models is that the abandonment of bank money and the relinquishment of the central bank responsibility for parity reconfigure the question of cash. In a CBDC design model with bank money, the existence of cash stands in the way of negative interest rates and thus curbs the central bank's ability to defend parity in situations with widespread mistrust in the commercial banking sector. This is what Huber is hinting at in the following:

Irritatingly, what central bankers seem to have in mind when reflecting on alternatives to traditional solid cash is the questionable aim of imposing without hindrance negative interest rather than worrying about monetary sovereignty. (Huber 2017, 189)

In a design model without bank money, the central bank has regained monetary sovereignty and is no longer forced to use interest rates or other monetary policy tools to maintain private bank money creation. Hence, the abolition of cash has no significant implications for the relation between the central bank and the commercial banks.

In turn, what is at stake in the question of cash is the relation between the central bank and the money users. This brings us back to the kinds of concerns raised in the money user scenario including issues of privacy, anonymity, security in crisis situations, and financial inclusion. The option to choose between holding cash and holding CBDC provides some measure of freedom and power to money users in their relation with the central bank. Even if the central bank is no longer compelled to defend parity between CBDC and bank money, it may still find it convenient to impose negative interest rates on CBDC. The existence of cash would again constitute some measure of restraint on this option. 


\section{Conclusion: Mint, Print and Type}

It is difficult to predict, which central bank is going to be the first to issue its own digital currency. As we have seen, the Swedish Riksbank seems to be one of the most progressive central banks in this respect. There is a certain historical curiosity to this fact.

In 1661 the first version of modern paper bank notes was issued by Stockholm Banco. The bank was privately owned but operated under a royal charter. The paper notes of the Stockholm Banco, kreditivsedlar as they were called, were initially backed by deposits of copper and subsequently silver but once the notes began to circulate as immediate means of payment, the bank was able to issue them not only against deposits of metal coins but also as loans. A combination of excessive money creation in excess of metal deposits and fluctuating metal prices due to import of foreign copper caused the system to collapse and the Stockholm Banco to enter into liquidation in 1664. After the liquidation, the bank was taken over by the Swedish state in 1668 , which is the point that the contemporary Riksbank today recognizes as its foundation.

The history of the kreditivsedlar and the Stockholm Banco is a story about the way that modern central banking emerged as a response to the invention of a new kind of money. The challenge posed by this new kind of money was of course that the production of paper money is not restricted by the availability of precious metals otherwise required to mint coins. There was a need for new laws and institutions to govern the issuance of money. In several other European countries we thus find similar stories about the way that national central banks were founded in the 17th, 18th and 19th century to administer the printing of money.

The contemporary question of CBDC is in many ways analogous to the historical questions of the birth of paper money. In the 20th century we have seen the invention of a new kind of money: electronic money. Just like the evolution of paper money in its time, the innovation of electronic means of payment has indeed made our economies more efficient and convenient and enabled entirely new forms of economic interaction. The introduction and proliferation of electronic money has, however, also introduced entirely new forms of risk and instability in 
the economy, which are also comparable to the ones brought about by paper money. The question of 21st century monetary policy is how to respond to these new forms of risk and instability.

The three scenarios for the implementation of CBDC are summarized in table 2: 
Table 2: Summary of CBDC scenarios

\begin{tabular}{|c|c|c|c|}
\hline & Money User Scenario & Money Manager Scenario & Money Maker Scenario \\
\hline Definition & Electronic Cash & Universal Reserves & Sovereign Account Money \\
\hline Perspective & Consumer & Bank & Citizen \\
\hline Function & Medium of exchange & Store of value & Unit of account \\
\hline Design & $\begin{array}{l}\text { Complimentary to cash and } \\
\text { bank money }\end{array}$ & $\begin{array}{l}\text { Complimentary to bank money } \\
\text { and replacement for cash }\end{array}$ & $\begin{array}{l}\text { Replacement for bank money } \\
\text { with or without cash }\end{array}$ \\
\hline Supply & $\begin{array}{l}\text { Demand driven. Central bank } \\
\text { supplies CBDC in response to } \\
\text { demand from commercial } \\
\text { banks, who respond to demand } \\
\text { from customers wanting to } \\
\text { hold CBDC instead of cash or } \\
\text { bank money. }\end{array}$ & $\begin{array}{l}\text { Demand driven. Central bank } \\
\text { supplies CBDC in response to } \\
\text { demand from banks, who } \\
\text { respond to demand from cus- } \\
\text { tomers wanting to hold CBDC } \\
\text { instead of bank money. }\end{array}$ & $\begin{array}{l}\text { Supply driven. Central bank } \\
\text { supplies CBDC in accordance } \\
\text { with monetary policy goals. } \\
\text { New CBDC are transferred to } \\
\text { the Treasury or directly to } \\
\text { money users. }\end{array}$ \\
\hline Exchange & $\begin{array}{l}\text { Commercial banks have privi- } \\
\text { lege to sell financial assets in } \\
\text { exchange for CBDC at the } \\
\text { central bank. }\end{array}$ & $\begin{array}{l}\text { Commercial banks have privi- } \\
\text { lege to sell financial assets in } \\
\text { exchange for CBDC at the } \\
\text { central bank. }\end{array}$ & $\begin{array}{l}\text { Commercial banks must ac- } \\
\text { quire CBDC in the open mar- } \\
\text { ket on par with all other mon- } \\
\text { ey users. All money users can } \\
\text { exchange cash for CBDC at } \\
\text { the central bank. }\end{array}$ \\
\hline Parity & $\begin{array}{l}\text { Central bank has responsibility } \\
\text { for parity between CBDC, cash } \\
\text { and bank money. }\end{array}$ & $\begin{array}{l}\text { Central bank has responsibility } \\
\text { for parity between CBDC and } \\
\text { bank money. }\end{array}$ & $\begin{array}{l}\text { Central bank has responsibility } \\
\text { for parity between CBDC and } \\
\text { cash. Commercial banks have } \\
\text { responsibility for the price of } \\
\text { any of their liabilities relative } \\
\text { to CBDC. }\end{array}$ \\
\hline Interest & $\begin{array}{l}\text { CBDC carry interest, which } \\
\text { may go into negative although } \\
\text { the existence of cash sets a de } \\
\text { facto lower bound }\end{array}$ & $\begin{array}{l}\text { CBDC carry interest, which } \\
\text { may go into negative. This } \\
\text { interest rate is used as a mone- } \\
\text { tary policy tool to defend } \\
\text { parity }\end{array}$ & $\begin{array}{l}\text { CBDC may or may not carry } \\
\text { interest. Money creation is the } \\
\text { primary monetary policy tool. } \\
\text { Interests are just a way of } \\
\text { creating new money or de- } \\
\text { stroying existing money. }\end{array}$ \\
\hline Seigniorage & $\begin{array}{l}\text { Central bank (treasury) earns } \\
\text { opportunity cost seigniorage on } \\
\text { CBDC and cash. Commercial } \\
\text { banks earn opportunity cost } \\
\text { seigniorage on bank money. }\end{array}$ & $\begin{array}{l}\text { Central bank (treasury) earns } \\
\text { opportunity cost seigniorage on } \\
\text { CBDC. Commercial banks } \\
\text { earn opportunity cost seignior- } \\
\text { age on bank money. The pos- } \\
\text { sibility of negative interest } \\
\text { rates may increase opportuni- } \\
\text { ties for seigniorage. }\end{array}$ & $\begin{array}{l}\text { Central bank (treasury) earns } \\
\text { monetary seigniorage on } \\
\text { CBDC. }\end{array}$ \\
\hline Politics & $\begin{array}{l}\text { Add efficiency to existing } \\
\text { system }\end{array}$ & Save existing system & Reform existing system \\
\hline
\end{tabular}


The scenarios not only differ in terms of the kind of solutions they provide. They also differ by their inherent identification of the challenge that needs to be addressed. This is what the final row of the table refers to.

The challenge identified in the money user scenario is largely a matter of user functionality. The responsibility of the central bank is to make sure that money functions optimally as a medium of exchange. The purpose of implementing $\mathrm{CBDC}$ is thus merely to add efficiency and functionality to the existing monetary system.

The challenge identified in the money manager scenario is slightly more severe. There is a risk that existing bank money shall become unable to perform their function as store of value. The business model of existing banks is under threat by financial instability on the one hand and fintech innovation on the other. The purpose of implementing CBDC is to provide central banks with better tools to defend the existing money and banking system.

The challenge identified in the money maker scenario is again a much more comprehensive political problem about sovereignty. Having largely relinquished the prerogative to create money, state monetary authorities have abandoned the most important tool to subject the economy to democratic control. The purpose of implementing CBDC is to reform the system by updating the traditional central bank monopoly on paper money to the digital age. 


\section{References}

Andolfatto, David. 2015. 'Should the Fed Issue Its Own Bitcoin?' Newsweek, December 31.

Bank of England. 2015. 'One Bank Research Agenda'. Discussion Paper. Bank of England.

- 2017. 'Digital Currencies'. Accessed March 20. http://www.bankofengland.co.uk/research/Pages/onebank/cbdc.aspx.

Barrdear, John, and Michael Kumhof. 2016. 'The Macroeconomics of Central Bank Issued Digital Currencies'. Staff Working Paper 605. Bank of England.

Binswanger, Hans Christoph, Joseph Huber, and Philippe Mastronardi. 2012. Die Vollgeld-Reform - wie Staatsschulden abgebaut und Finanzkrisen verhindert werden können. Solothurn: Edition Zeitpunkt.

Bjerg, Ole. 2013. Gode Penge: Et Kontant Svar På Gøldskrisen. København: Informations Forlag.

- 2014. Making Money - The Philosophy of Crisis Capitalism. London: Verso.

Broadbent, Ben. 2016. 'Central Banks and Digital Currencies'. Speech at London School of Economics.

Camera, Gabriele. 2017. 'A Perspective on Electronic Alternatives to Traditional Currencies'. Sveriges Riksbank Economic Review, No. 1: 126-48.

Carney, Mark. 2016. 'Enabling the FinTech Transformation: Revolution, Restoration, or Reformation?' Speech by the Governor. Lord Mayor's Banquet for Bankers and Merchants of the City of London at the Mansion House. Bank of England.

Cleland, Victoria. 2016. 'Fintech: Opportunities for All?' Speech by the Chief Cashier. 2nd International Workshop P2P Financial Systems. Bank of England.

Dyson, Ben, and Graeme Hodgson. 2016. 'Digital Cash: Why Central Banks Should Issue Digital Currency'. London: Positive Money.

Dyson, Ben, and Andrew Jackson. 2013. Modernising Money. London: Positive Money.

Fiedler, Salomon, Klaus-Jürgen Gern, Stefan Kooths, and Ulrich Stolzenburg. 2017. 'Financial Innovation and Monetary Policy: Challenges and Prospects'. Monetary Dialogue - In-Depth-Analysis. European Parliament.

Fleming, J. Marcus. 1962. 'Domestic Financial Policies under Fixed and under Floating Exchange Rates'. IMF Economic Review 9 (3): 369-380. 
foundery. 2016. 'The Advent of Crypto Banking - A New Paradigm for Central and Commercial Banking'. FirstRand Bank Ltd.

Fung, Ben SC, and Hanna Halaburda. 2016. 'Central Bank Digital Currencies: A Framework for Assessing Why and How'. Staff Discussion Paper. Ontario: Bank of Canada.

Gouveia, Olga, Enestor Dos Santos, Alejandro Neut, and Javier Sebastián. 2017. 'Central Bank Digital Currencies: Assessing Implementation Possibilities and Impacts'. Working Paper. Madrid: BBVA.

Graeber, David. 2011. Debt: The First 5,000 Years. New York: Melville House.

Haldane, Andrew. 2015. 'How Low Can You Go'. Speech by Chief Economist. Portadown Chamber of Commerce, Northern Ireland. Bank of England.

Huber, Joseph. 2014. Monetäre Modernisierung. Zur Zukunft der Geldordnung: Vollgeld und Monetative. Marburg: Metropolis.

—. 2017. Sovereign Money - Beyond Reserve Banking. Cham: Palgrave Macmillan.

Huber, Joseph, and James Robertson. 2000. Creating New Money: A Monetary Reform for the Information Age. London: New Economics Foundation.

Innes, A. Mitchell. 1913. 'What Is Money'. The Banking Law Journal 30: 377. . 1914. 'Credit Theory of Money'. The Banking Law Journal 31: 151.

Jackson, Andrew, and Ben Dyson. 2012. Modernising Money: Why Our Monetary System Is Broken and How It Can Be Fixed. London: Positive Money.

Ketterer, Juan Antonio, Gabriela Andrade, Juan Antonio Ketterer, Gabriela Andrade, Juan Antonio Ketterer, Gabriela Andrade, Juan Antonio Ketterer, and Gabriela Andrade. 2016. 'Digital Central Bank Money and the Unbundling of the Banking Function'. Discussion Paper. Inter-American Development Bank.

Keynes, John M. 1930. A Treatise On Money. London: Macmillan.

Knapp, Georg Friedrich. 1924. The State Theory of Money. London: Macmillan and Company.

Koning, J. P. 2016. 'Fedcoin: A Central Bank-Issued Cryptocurrency'. November 15: 2016.

McLeay, Michael, Amar Radia, and Ryland Thomas. 2014. 'Money Creation in the Modern Economy'. Quarterly Bulletin 54 (1): 14-27.

Mersch, Yves. 2017. 'Digital Base Money: An Assessment from the ECB's Perspective'. Speech by Member of the Executive Board. The Farewell Ceremony for Pentti Hakkarainen, Deputy Governor of Suomen Pankki Finlands Bank. European Central Bank.

Mundell, Robert A. 1963. 'Capital Mobility and Stabilization Policy under Fixed and Flexible Exchange Rates'. Canadian Journal of Economics and Political Science/Revue Canadienne de Economiques et Science Politique 29 (04): 475-485. 
Obstfeld, Maurice, and Alan M. Taylor. 1997. 'The Great Depression as a Watershed: International Capital Mobility over the Long Run'. Working Paper 5960. National Bureau of Economic Research.

—. 2002. 'Globalization and Capital Markets'. Working Paper 8846. Cambridge MA: National Bureau of Economic Research.

Powell, Jerome H. 2017. 'Innovation, Technology, and the Payments System'. Speech. Blockchain: The Future of Finance and Capital Markets? The Yale Law School Center for the Study of Corporate Law, New Haven, Connecticut.

Ryan-Collins, Josh, Tony Greenham, Richard Werner, and Andrew Jackson. 2011. Where Does Money Come From? - A Guide to the UK Monetary and Banking System. London: New Economics Foundation.

Schumpeter, Joseph A. 1934. The Theory of Economic Development. New Brunswick, N.J: Transaction Publishers.

Skingsley, Cecilia. 2016. 'Should the Riksbank Issue E-Krona?' Speech by the Deputy Governor. FinTech Stockholm. Stockholm: Sveriges Riksbank.

Smith, Adam. 1776. The Wealth of Nations. New York: The Modern Library.

Werner, Richard. 2005. New Paradigm in Macroeconomics: Solving the Riddle of Japanese Macroeconomic Performance. Basingstoke: Palgrave Macmillan.

Yifei, Fan. 2016. 'On Digital Currencies, Central Banks Should Lead'. Bloomberg View, September 1. 